\title{
Determining the responses of vegetation to natural processes and human impacts in north-eastern Poland during the last millennium: combined pollen, geochemical and historical data
}

\author{
Agnieszka Wacnik ${ }^{1}$ Wojciech Tylmann ${ }^{2}$ Alicja Bonk ${ }^{2}$ - Tomasz Goslar ${ }^{3,4}$ • \\ Dirk Enters $^{5} \cdot$ Carsten Meyer-Jacob $^{6} \cdot$ Martin Grosjean $^{7}$
}

Received: 16 November 2015/Accepted: 8 March 2016/Published online: 17 March 2016

(c) The Author(s) 2016. This article is published with open access at Springerlink.com

\begin{abstract}
Pollen, charcoal and geochemical investigations were carried out on annually laminated sediments of Lake Żabińskie $\left(54^{\circ} 07^{\prime} 54.5^{\prime \prime} \mathrm{N} ; 21^{\circ} 59^{\prime} 01.1^{\prime \prime} \mathrm{E}\right)$ and the results were combined with historical and climate data to better understand the mechanism behind plant cover transformations. A millennium-long record of environmental history at 6-years time resolution permitted an assessment of vegetation responses to past human impact and climate fluctuations. Our results show that the history of the region with repeated periods of warfare, epidemics, famine and crop failures is well reflected by environmental proxies. Before the Teutonic Order crusade (AD 1230-1283), agricultural activities of the Prussian tribes were conducted at a distance from the studied lake and
\end{abstract}

Communicated by M.-J. Gaillard.

Agnieszka Wacnik

a.wacnik@botany.pl

1 W. Szafer Institute of Botany Polish Academy of Sciences, Lubicz 46, 31512 Kraków, Poland

2 Faculty of Oceanography and Geography, University of Gdańsk, Bażyńskiego 4, 80952 Gdańsk, Poland

3 Faculty of Physics, Adam Mickiewicz University, Umultowska 85, 61614 Poznań, Poland

4 Poznań Radiocarbon Laboratory, Foundation of the Adam Mickiewicz University, Rubież 46, 61612 Poznań, Poland

5 GEOPOLAR, Institute of Geography, University of Bremen, Celsiusstr. FVG-M, 28359 Bremen, Germany

6 Department of Ecology and Environmental Sciences, Umeå University, Linnaeus väg 6, 90187 Umeå, Sweden

7 Oeschger Centre for Climate Change Research and Institute of Geography, University of Bern, Erlachstrasse 9a, 3012 Bern, Switzerland caused slight disturbances of local forests. A stronger human impact was registered after ca AD 1460. We confirm that co-domination of pine forests with spruce and oakhornbeam forests on drier habitats as well as the presence of birch and alder woods on wet surfaces near the lake lasted until AD 1610. We identified a transition period of 20 years between AD 1590 and 1610, when forest cover was significantly reduced and the area was partly transformed into open land used for farming activities. The comparison of our data with other pollen datasets from the region confirms significant spatio-temporal differences in the initiation of large-scale woodland clearings in the Great Masurian Lake District. A strong increase in local cultivation was noted after AD 1750 and became even stronger in the period AD 1810-1940. The last 60 years experienced a succession from arable fields and open grasslands to more tree-covered habitats overgrown by birch and alder.

Keywords Human impact on woodland P Palynology · Erosion · Varved sediments · High time-resolution · Prussia

\section{Introduction}

It is well-known that lake-catchment systems respond physically, chemically and biologically to climatic and environmental changes (e.g. Oldfield 1977; O'Sullivan 1983; Ralska-Jasiewiczowa et al. 2003). In comprehensive palaeoenvironmental and palaeoclimatic studies, pollen analysis supplemented by data on fire frequencies (e.g. Pitkänen and Huttunen 1999; Mooney and Tinner 2011) is the basic source of information about natural and anthropogenic changes in terrestrial and aquatic vegetation. Holocene vegetation features recorded in pollen deposition reflect both short lasting vegetation disturbances and 
prolonged changes caused by natural climatic processes. Pollen also recorded the history of local human economic and settlement activities. A distinct change from wooded to partly open environments with high proportions of agrocenoses and semi-natural woods is reflected fairly well in pollen diagrams.

The last millennium was the key period for the development of modern vegetation types and the formation of cultural landscapes. It was also a time of significant climatic variations. Commonly registered in different proxyarchives are the Medieval Climate Anomaly (MCA; ca AD 750-1250), the Little Ice Age (LIA; ca AD 1250-1850) and the Anthropogenic Recent Warmth (ARW; ca AD 1850-present) (e.g. Briffa 2000; Büntgen et al. 2006, 2013). Investigating variations in such relatively short periods of time requires high-resolution pollen analysis, which is considered to be a priority in modern multidisciplinary investigations of palaeoenvironmental changes (e.g. Tinner and Lotter 2006). The best results are obtained from the precise analysis of sediments formed in aquatic environments and characterized by varved sediment structures that reflects annual depositional cycles (e.g. Sturm 1979; Tylmann et al. 2013; Zolitschka et al. 2015). This sediment type allows the establishment of an absolute high-resolution chronology, which is essential for reliable correlation of palaeoecological records with historical data. In varved sediments it is possible to assess yearly flux rates of pollen, to define rates of palaeoenvironmental changes and to describe them on decadal and even subdecadal scales (Birks and Birks 2006). Holocene palaeoecological reconstructions including pollen studies from varved sediments were obtained for several European areas, for instance in Scandinavia (Anderson et al. 1996; Haltia-Hovi 2010; Ojala et al. 2008), Germany (Kerig and Lechterbeck 2004; Kubitz 2000; Leroy et al. 2000; Litt et al. 2001; Voigt et al. 2008), Switzerland (e.g. Haas et al. 1998; Lotter 1999; Tinner et al. 2003) and France (e.g. Stebich et al. 2005). In the south-east Baltic area, the chronologically most precise palaeoenvironmental data for the last millennium were obtained from the analysis of laminated sediments of Lakes Gościąż (Ralska-Jasiewiczowa et al. 1998), Suminko (Pędziszewska et al. 2015), Łazduny (Wacnik et al. 2012), Szurpiły (Kinder et al. 2008; Kupryjanowicz pers. comm.) and Lake Czechowskie (Obremska et al. 2014) in Poland and Lake Rõuge Tõugjärv in Estonia (Alliksaar et al. 2005; Veski et al. 2005).

During the last two decades, detailed studies of vegetation changes in northeastern Poland contributed significantly to a better understanding of the postglacial vegetation history in the whole Baltic area of Europe. Despite the fact that 80 years have passed since the first palynological investigations were conducted in the Masurian Lake District (Kupryjanowicz 2008) serious gaps still exist in our knowledge of the postglacial changes in the natural environments of that region. These deficiencies result from, among others, a small number of sites having long pollen records representing postglacial vegetation changes, and from the scarcity of palaeoecological reconstructions including in particular modern times. Our interdisciplinary investigation of varved sediments from Lake Żabińskie was undertaken in response to the lack of high-resolution palaeoecological studies for the last millennium in the southern Baltic region. The main goal of our research was to establish a detailed reconstruction of the vegetation history, land-use changes and the human impacts on the environment of the Great Masurian Lake District. We show that high-resolution pollen analysis of annually laminated sediments is a very accurate and powerful method for examining the influence of the local historical settlement events on the vegetation in a longer-term perspective. To achieve this, we (i) reconstructed the rates, extent and permanence of plant cover changes and fire history; (ii) analysed geochemical sedimentary parameters indicative of erosion changes in the lake catchment; and (iii) verified our vegetation and disturbance regime reconstructions with independent documentary data.

\section{Regional setting}

\section{Present day situation}

According to the physico-geographical regionalization of Poland, Lake Żabińskie is situated in the NE part of the Great Masurian Lake District mesoregion, which is a part of the Masurian Lake District macroregion (Kondracki 2002). The landscape topography in the area was formed during the Pomeranian Phase of the Weichselian glaciation (Fig. 1). The characteristic feature is a large number of lakes, peatlands and gyttja lands (Gotkiewicz et al. 1995). The present climate is characterized by distinct continentality and is one of the coldest in Poland with a mean annual temperature of $6.5^{\circ} \mathrm{C}$ (mean January temperature is $-4.5^{\circ} \mathrm{C}$, mean July temperature is $17.5^{\circ} \mathrm{C}$; Woś 1999 ). Annual precipitation is ca $570 \mathrm{~mm}$ with summer rainfall predominant (Siuta 1994). The snow cover persists for $1.5-3$ months. The length of the growing season is about $180-190$ days.

Zonal soils, namely brown soils and podzols predominate. Hydrogenic and semi-hydrogenic soils cover the lowlying terrains along rivers and near lakes (Bednarek and Prusinkiewicz 1999).

In accordance with the geobotanical division of Poland, the Masurian Lake District lies within the Northern Division, Mazury-Kurpie Province (Szafer and Zarzycki 1972). 
Fig. 1 a Location of the Great Masurian Lake District area in relation to the Weichselian ice sheet extent. b Map of the potential natural vegetation in Lake Żabińskie area (after Matuszkiewicz 2008b) 1 TilioCarpinetum, 2 Carici elongataeAlnetum, 3 Fraxino-Alnetum, 4 Querco-Pinetum, 5 PeucedanoPinetum, 6 lakes. $\mathbf{c}$ Location of Lake Żabińskie in relation to the nearest palynological profiles containing sediments deposited during the last two millennia with radiocarbon datings

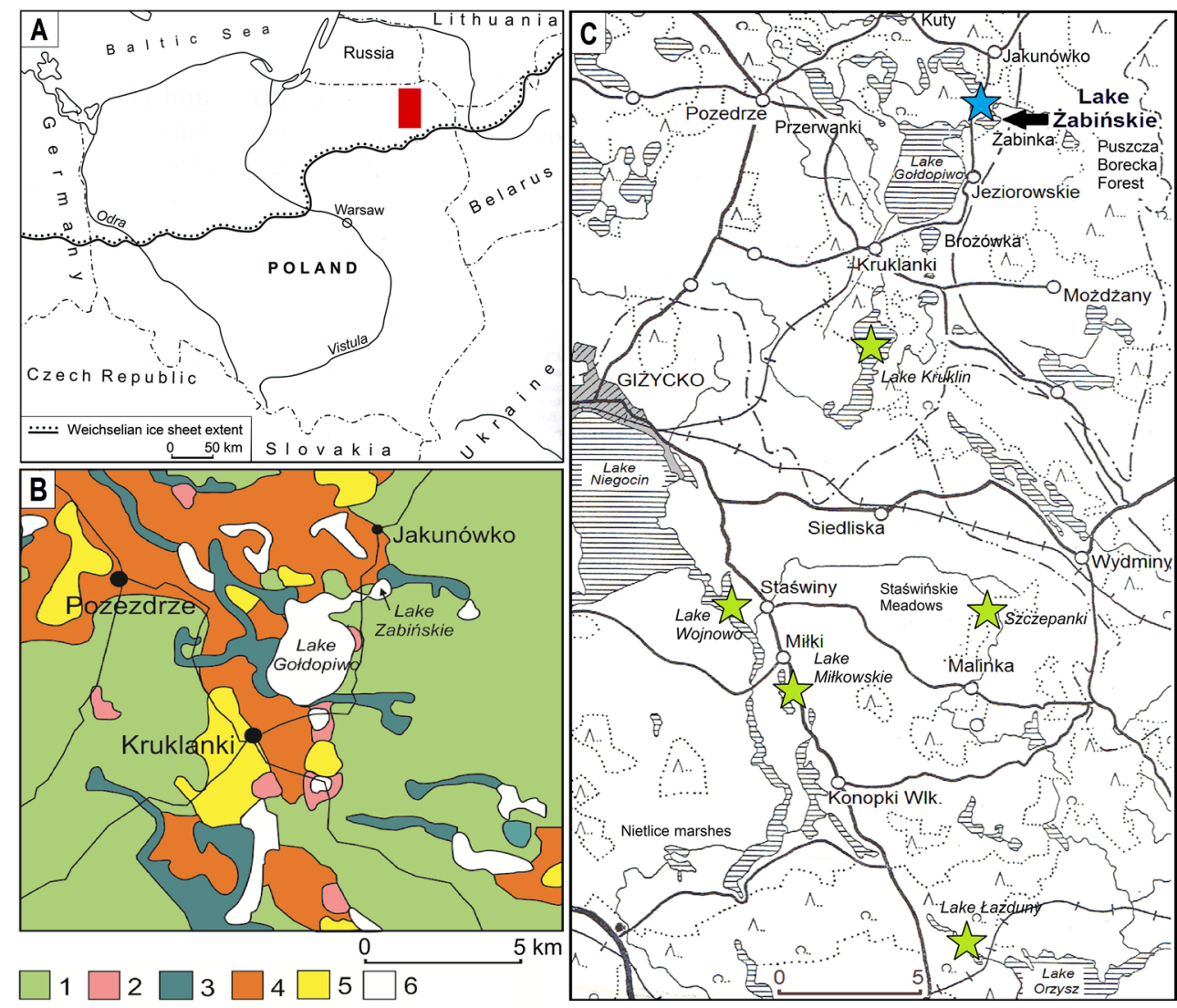

The potential natural vegetation of the studied area is composed predominantly of the subboreal type of lowland lime-oak-hornbeam forests with spruce and lowland alder. Ash-alder forests are found on periodically swamped ground-water soils in the area of former lakes. Small patches of middle-European alder fen forest, subxero-termophilous sarmatian oak and pine-oak forests and continental East-European pine forests with spruce, as well as continental mesotrophic oak-pine mixed forest and some areas of continental swamp pine forest, are also present (Matuszkiewicz 2008a).

Nowadays, woodland communities cover ca $30 \%$ of the surface. Among them different types of pine and mixed pine forests prevail on sandy soils while oak-lime-hornbeam forests develop in morainic areas on more fertile substrates (Matuszkiewicz 2002, 2008b). The area is located on the border of continuous distribution of Fagus sylvatica and Acer pseudoplatanus (e.g. Zając and Zając 2001).

\section{Historical background}

The medieval time was important for the whole southeastern and eastern Baltic area due to the introduction of Christianity by the Teutonic Knights, and subsequent significant economic development, political, administrative and ethnical changes (Biskup et al. 2008; Okulicz-Kozaryn
1997; Pluskowski 2013). The period between the 9th and 13th centuries AD includes the formation of the Polish State by the Piast Dynasty (Buko 2005). Before the conquest by the Teutonic Order in AD 1283, the Prussian territory was divided among eleven tribes. One of the tribes that inhabited the area of Lake Żabinskie were the Galindians. "The Holy War" against the Prussians in the second half of the 13th century AD brought about the conquest of these territories by crusaders and the formation of the Catholic theocratic State ruled by the Teutonic Order. It was also a time of growing importance of the Hansa trading network in Europe, which influenced the economy of the Teutonic state (Ważny 2005; Pluskowski 2013). After the secularisation of Teutonic Order estates, a few particularly important periods can be distinguished in the regional history, such as the formation of the Duchy of Prussia ( $\mathrm{AD}$ 1525-1618), the union with Brandenburg (AD 1618-1701) and the Kingdom of Prussia (AD 1701-1871). Considerable prosperity began in the second half of the 19th century AD when, after the end of the war with France in AD 1870, the funds from the French contribution were allocated to the development of industry, infrastructure and agriculture in East Prussia (Achremczyk 2010a, b). The next important historical period was the creation of the German Empire (AD 1871-1918), followed by the formation of the Free State of Prussia (from AD 1919 to the abolition in 1934). 
Finally, after Germany's defeat in World War II, West Prussia and East Prussia were divided by Poland and the Soviet Union. The majority of the Prussian population living in NE Poland was evacuated, fled or was expelled to Germany (AD 1944-1950) and people from the eastern borderlands of Poland (Wilno, Grodno regions and some regions of the Western Ukraine), as well as from Masovia and the Polish Carpathians, were resettled in their place. Until the independence of Poland from the Soviet Union in 1989, followed by political, administration and economical changes, the structure of agriculture in the Masurian Lake District area was based on the large state farms which replaced former granges. Farm ownership changed after the 1990s. However, the economy continued to be based on agriculture after the collapse and privatization of the state farms (Achremczyk 2010b).

\section{Materials and methods}

\section{Study site}

Lake Żabińskie $\left(54^{\circ} 07^{\prime} 54.5^{\prime \prime} \mathrm{N} ; 21^{\circ} 59^{\prime} 01.1^{\prime \prime} \mathrm{E} ; 116.8 \mathrm{~m}\right.$ a.s.l.) is a postglacial lake (Fig. 1). The surface area is 40.6 ha and the maximum water depth is $44.4 \mathrm{~m}$ in the central part of the main basin, from where the varved sediment sequence was recovered. The lake is connected with the smaller Lake Purwin in the northeastern part and with the much larger Lake Gołdopiwo located to the southwest. Today, Lake Żabińskie is highly productive with a calcium-rich epilimnion and a seasonally anoxic hypolimnion (Bonk et al. 2015a).

\section{Sediment collection and subsampling}

Overlapping sediment cores consisting of varved sediments were collected from the deepest part of Lake Żabińskie during two field surveys in 2011 and 2012 using UWITEC gravity and piston corers $(\varnothing 90 \mathrm{~mm})$. The composite sediment profile was obtained by stratigraphic correlation based on macro- and microscopic comparison of wellpreserved laminations and diagnostic horizons (Bonk et al. 2015b). Half $A$ of the composite sediment profile was subsampled continuously for thin sections while half B of the composite sediment profile was subsampled at 3-year resolution according to varve boundaries for discrete multiproxy analysis.

\section{Sediment chronology}

Thin sections were microscopically analysed to identify typical varve microfacies in the sediment profile. Next three people counted the number of varves on high-resolution digital images of thin sections and the final chronology and its uncertainty was estimated. The varve chronology for Lake Żabińskie covers the period from $\mathrm{AD}$ 1000-2011 (Bonk et al. 2015a; Fig. 2). Counting uncertainty at $\mathrm{AD} 1000$ is in the range of $1-3 \%(+12 /-24$ varve years) which underlines the good preservation of the varves and the reliability of the chronology. The varve thickness was measured along three parallel lines (middle, left- and right-side of the thin sections) to account for horizontal variability within one varve. A mean from three different measurements was calculated and defined as the varve thickness.

Down to 900 varve years, the varve chronology is supported by $32 \mathrm{AMS}{ }^{14} \mathrm{C}$ dates distributed along the sediment profile (Bonk et al. 2015b; Fig. 2). After botanical identification at the Department of Plant Ecology (University of Gdańsk), only well-preserved terrestrial plant fragments were selected and dated by ${ }^{14} \mathrm{C}$ AMS technique at the Poznań Radiocarbon Laboratory. The radiocarbon ages were calibrated using the INTCAL13 (Reimer et al. 2013) and the BombNH1 (Hua et al. 2013) calibration curves. The ${ }^{14} \mathrm{C}$ chronology was established with the free-shape algorithm (Goslar et al. 2009). Additionally, the chronology of the topmost part of the sediment was validated with independent dating methods, i.e. ${ }^{137} \mathrm{Cs}$ activity peaks and

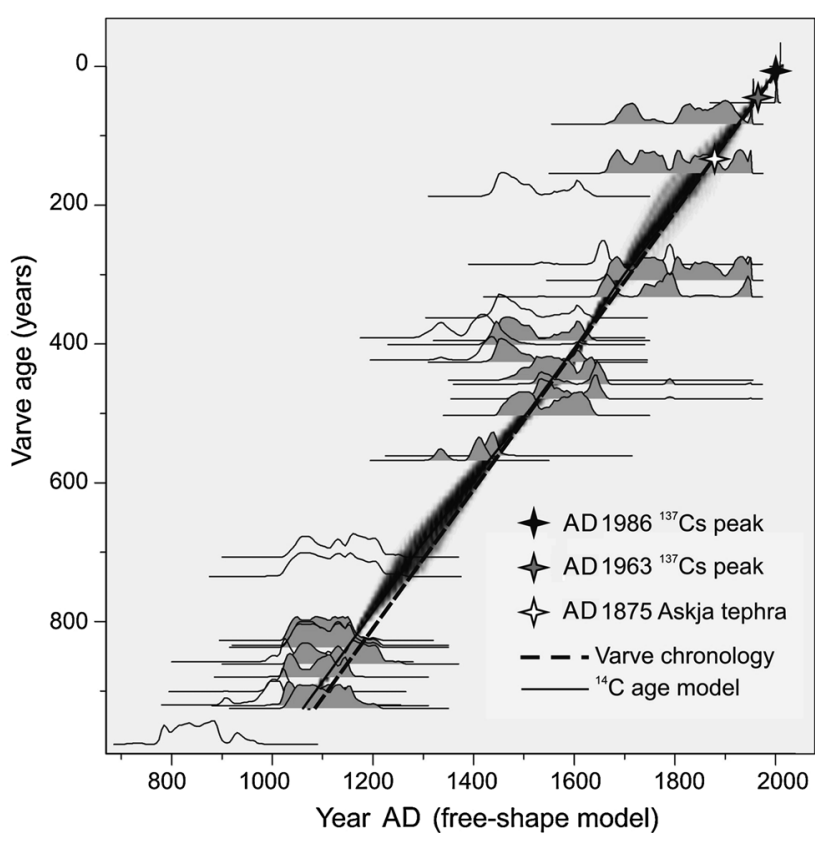

Fig. 2 Chronology of the sediment core of Lake Żabińskie (Bonk et al. 2015b). The ${ }^{14} \mathrm{C}$-based age model (grey-shaded band passing through the probability distributions of the calibrated ${ }^{14} \mathrm{C}$ dates) is compared with the varve chronology represented by the dashed line. The stars represent independent age markers, as described by Tylmann et al. (2016) 
the Askja AD 1875 tephra horizon (Tylmann et al. 2016). After these successful validations we accepted the varve chronology as the time scale for all diagrams presenting pollen and geochemical results.

\section{Palynology}

Samples for pollen analysis $\left(1\right.$ or $\left.0.5 \mathrm{~cm}^{3}\right)$ were collected according to varve boundaries (stratigraphic sampling), always containing three varves (years) in each sample. Every second sample was prepared for analysis with the modified Erdtman's acetolysis method (Berglund and Ralska-Jasiewiczowa 1986). With this procedure a palynological sequence with a time resolution of 6 years was obtained. Along with pollen grains on the same slides, charcoal microfragments were counted in every second sample (i.e. one data point with three varve-years integrated per 12 years). Two size groups were recorded, $10-100 \mu \mathrm{m}$ and $>100 \mu \mathrm{m}$. In order to estimate pollen and charcoal concentrations Lycopodium tablets with a specified number of spores were added (Stockmarr 1971). Pollen counting was continued until a number of ca 800 grains of trees and shrubs was achieved in each of the 159 studied samples. For pollen identification, keys (e.g. Beug 2004) and the reference collection of modern pollen of the W. Szafer Institute of Botany, Polish Academy of Sciences in Kraków were used. Percentage values of taxa were calculated from the total sum, i.e. the number of tree and shrub pollen grains (arboreal pollen-AP) and dwarf-shrubs and herbaceous terrestrial plant pollen grains (non-arboreal pollen-NAP). The percentage pollen values of aquatic and swamp taxa, and spores of cryptogams were determined on the basis of the total sum plus the number of the respective sporomorphs. The results are presented in pollen diagrams drawn on a chronological scale with POLPAL for Windows software (Nalepka and Walanus 2003). Local Pollen Assemblage Zones (L PAZ) were distinguished in the pollen diagram. Both the traditional method of spectra comparison and the ConSLink numerical method were used to determine zone boundaries. The estimation of changes in palynological richness was based on rarefaction analysis E (T minimal pollen sum) calculated using the application RAREF included in POLPAL (Nalepka and Walanus 2003, http://www.adamwalanus.pl/Polpal.html). For selected taxa, pollen accumulation rates (PARs) were calculated (Davis and Deevey 1964; Seppä et al. 2009).

\section{Geochemical analyses}

The composite profile was scanned with an ITRAX XRF core scanner (Cox Analytical Systems) for the detection of major and trace elements. The scanning was conducted at GEOPOLAR (University of Bremen) using a Mo tube
$(30 \mathrm{kV}, 18 \mathrm{~mA})$ with a step size of $0.2 \mathrm{~mm}$ and a count time of $10 \mathrm{~s}$ per step. Counts of elements were normalized by coherent radiation to reduce the sediment matrix effect (Croudace et al. 2006). In this study we used only selected elements $(\mathrm{Ti}, \mathrm{Fe} / \mathrm{Mn})$ to show changes in intensity of erosion in the catchment (Enters et al. 2010) and redox conditions (Wersin et al. 1991). Biogenic silica (BSi) concentrations, which provide information about the diatom abundance in the sediment and thus about the in-lake production, were measured by Fourier transform infrared spectroscopy (FTIR) according to the methodology described by Vogel et al. (2008). FTIR-spectral information was calibrated against wet-chemically measured BSi concentrations that were determined in 113 samples from Lake Żabińskie (3-70\%, in $\% \mathrm{SiO}_{2}$ ) using the method described by Ohlendorf and Sturm (2008). The internal calibration model between FTIR-inferred and wet-chemically measured BSi values has a cross-validated $R^{2}$ of 0.82 and an RMSECV of $5.7 \%$ (root mean square error of cross-validation).

\section{Results}

\section{Palynology}

Selected results of pollen and spores supplemented by charcoal counting data are shown in Figs. 3 and 4. Six distinguished local pollen zones describe terrestrial vegetation changes which occurred between AD 1000 and 2010 .

The first zone (L PAZ LZ 1; Betula-Pinus-Carpinus (Quercus); AD 1000-1125) is characterised by the highest Betula percentages values (up to $47 \%$ ) with a decreasing tendency after AD 1057. High but variable Pinus sylvestris values range from 14 to $46 \%$. Considerable proportions of Quercus (up to $9 \%$ ), Carpinus betulus (up to $13 \%$ ) and Picea abies (up to $7.2 \%$ ) are noted. Alnus frequency (11\%) shows weakly increasing trends. The PARs of trees and shrubs are high and reach 35,000 pollen grains $\mathrm{cm}^{-2}$ year ${ }^{-1}$ on average (Fig. 5). Charcoal microparticles are present but relatively low with accumulation rates (ChAR) around 1700 particles $\mathrm{cm}^{-2}$ year ${ }^{-1}$ on average (Fig. 4).

In the second zone (L PAZ LZ 2; Carpinus-QuercusAlnus (Picea); AD 1125-1440) AP predominates and reaches the highest values in the profile $(96 \%)$. Proportions of $P$. sylvestris vary between 16 and $44 \%$. Betula pollen decreases significantly from 30 to $18 \%$ on average. Characteristic is the increase of $C$. betulus (AD 1415; up to $26 \%$ ) and Picea abies pollen (since AD 1350; up to $15 \%$ ). A significant rise of Quercus pollen frequency (AD 1130; $10-12 \%)$ is followed by a slight decline. The highest 


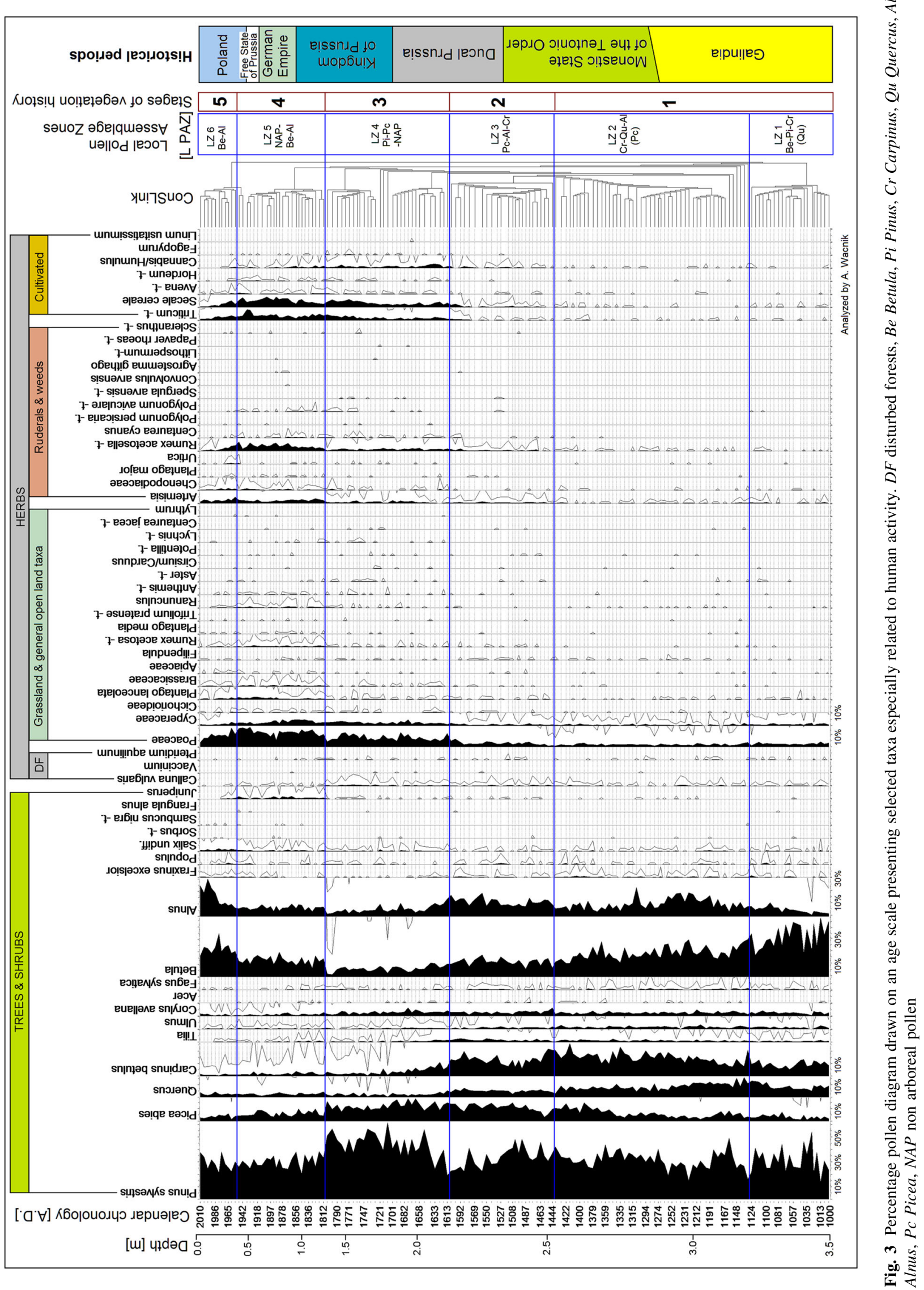




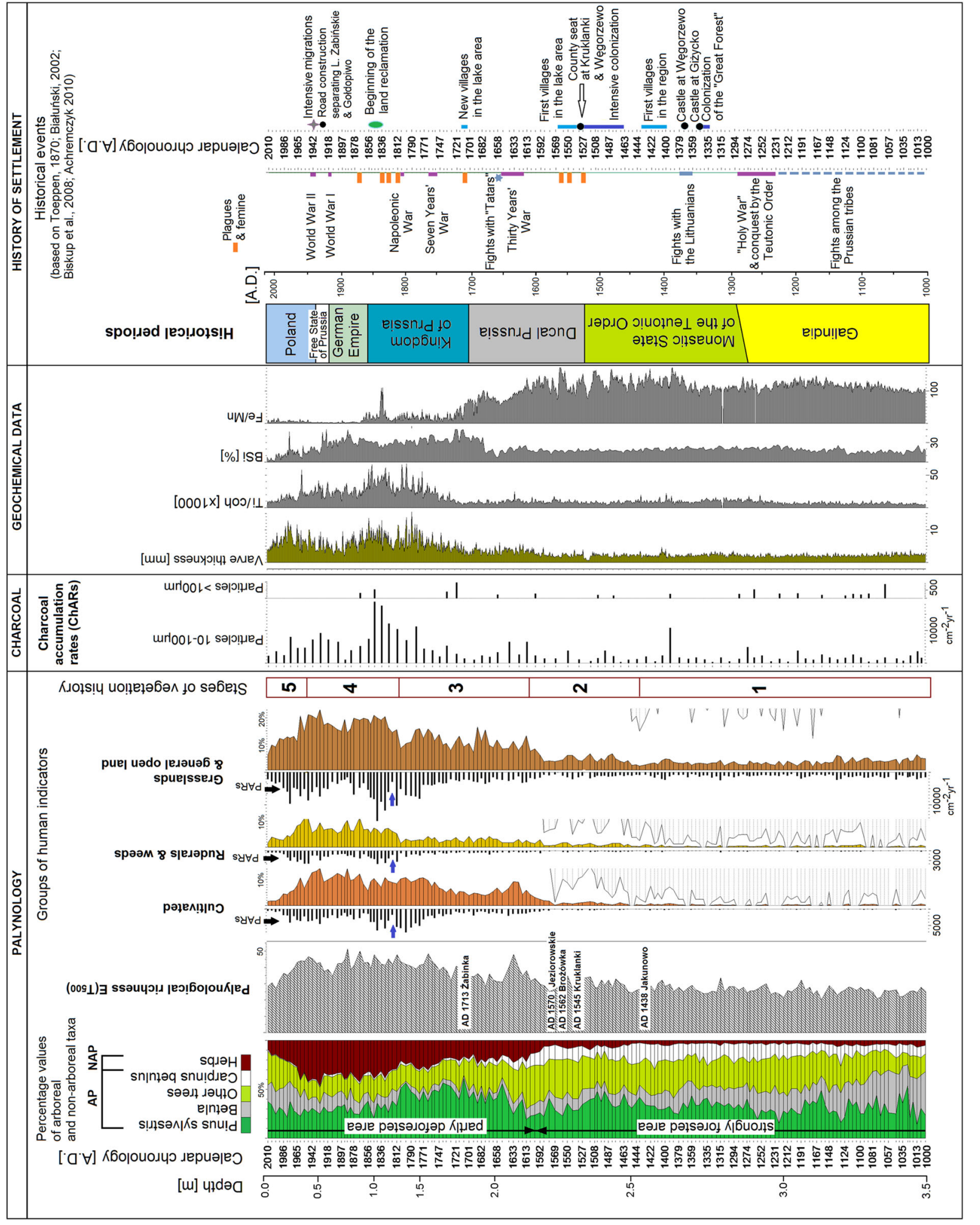

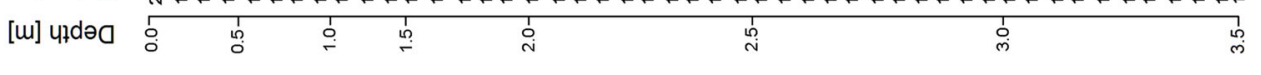




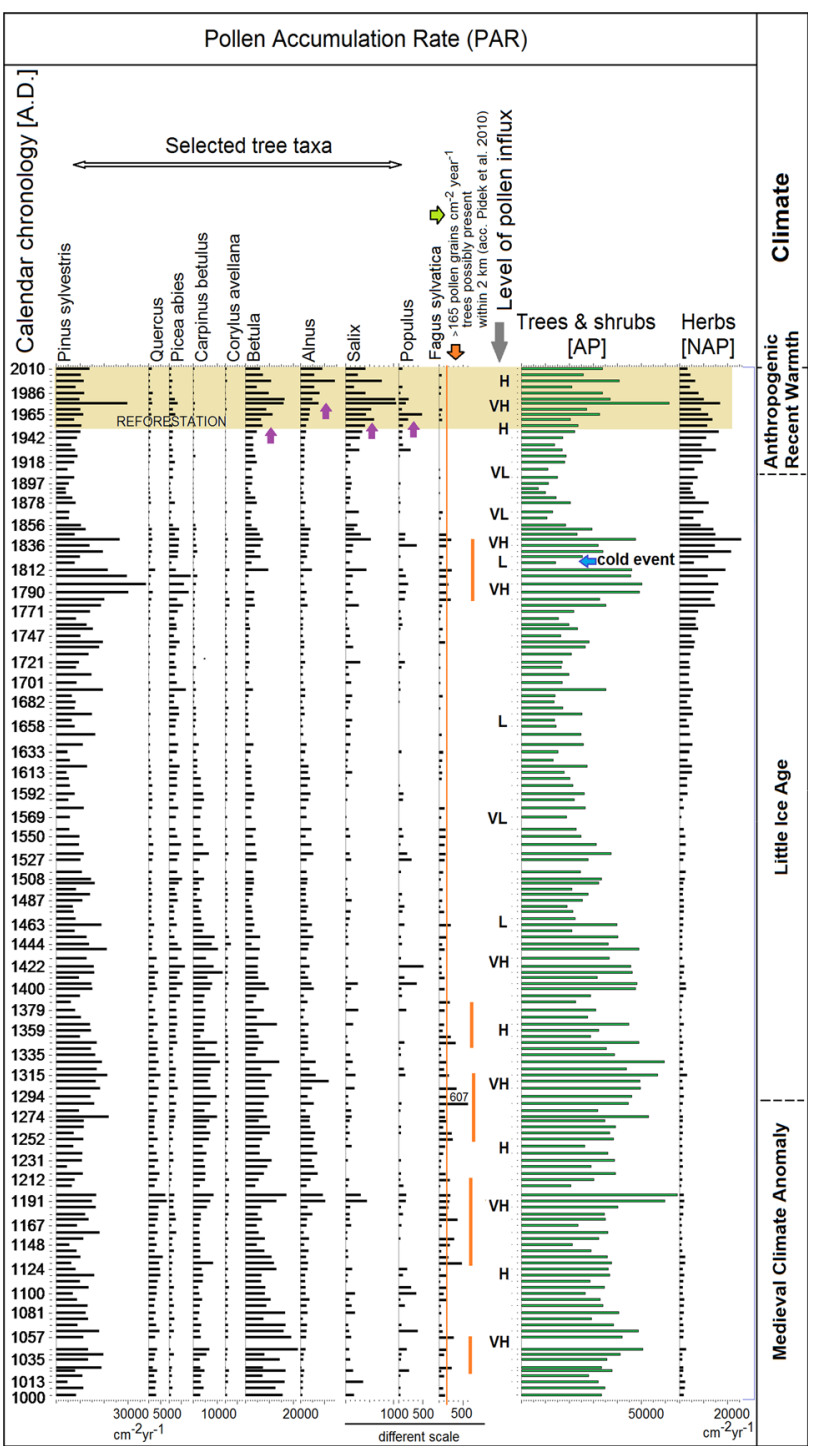

Fig. 5 Histograms presenting pollen accumulation rates of the main forest forming taxa and total herbs. Reforestation is marked with arrows in the upper part of the diagram. $V H$ very high, $H$ high, $L$ low, $V L$ very low

influx of AP in this zone reaches 35,000 pollen grains $\mathrm{cm}^{-2}$ year ${ }^{-1}$ on average. Values of ChARs are slightly higher (up to 10,900 particles $\mathrm{cm}^{-2}$ year ${ }^{-1}$ ).

The characteristic feature of the third zone (L PAZ LZ 3; Picea-Alnus-Carpinus; AD 1440-1610) is the increase of P. abies (especially since AD 1490; up to $14 \%$ ) and Alnus (up to $19 \%$ ). Initially high frequencies of C. betulus (22\%) decrease to mean values of ca $12 \%$ between $\mathrm{AD}$ 1465 and 1520 . The initial rise of $P$. sylvestris since AD 1535 is followed by a decline to mean values of $25 \%$. C. avellana frequency is slightly higher with values up to $7 \%$. Among the NAP, indicators of agriculture appear regularly. Continuous presence of cultivated plants such as Secale cereale and Triticum-type begins after AD 1580. The group of ruderals and field weeds is almost continuously represented by Artemisia, Rumex acetosella-type, Chenopodiaceae, Centaurea cyanus and Plantago major. PARs of AP decrease at ca $\mathrm{AD} 1460$ from ca 35,000 to 24,000 pollen grains $\mathrm{cm}^{-2}$ year $^{-1}$ (Fig. 5). Initially, low ChARs with 1,600 particles $\mathrm{cm}^{-2}$ year $^{-1}$ on average increase between AD 1480-1495 and around 1550 and 1600 (Fig. 4).

The forth zone (L PAZ LZ 4; Pinus-Picea-NAP; AD 1610-1810) is characterised by a strong reduction of AP percentages including C. betulus (from 13 to $2 \%$ ), Betula (from 10 to $3 \%$ ), Quercus (from 5 to $2 \%$ ), Alnus (from 17 to $3 \%$ ) and a significant increase of $P$. sylvestris (from 20 to $60 \%$ ). A sharp rise in grassland pollen (Poaceae) and cultivated plants (Secale cereale up to $4 \%$; Triticum-type up to $2.4 \%$; Cannabis/Humulus pollen up to $3 \%$ ) is registered. Ruderals and weeds are represented especially by Artemisia (2\%), Rumex acetosella-type (2.3\%) and, less frequently, by Centaurea cyanus, Polygonum aviculare and Chenopodiaceae. A maximum of grasses and sedges is registered between $A D 1680$ and 1690 when representatives of cultivated plants slightly decrease. PARs of AP are generally lower, although they reach highest values with ca 45,000 pollen grains $\mathrm{cm}^{-2}$ year $^{-1}$ towards the end of the fourth zone (AD 1790-1810). The highest PARs of NAP are noted between $\mathrm{AD} 1780$ and 1810. ChARs reach mean values of 4,900 particles $\mathrm{cm}^{-2}$ year $^{-1}$ in the periods $\mathrm{AD}$ 1615-1660 and AD 1720-1800 (Fig. 4).

In the fifth zone (L PAZ LZ 5; NAP-Betula-Alnus; AD 1810-1950), a further decline of AP frequency is clearly marked. This drop is particularly strong in the cases of $P$. sylvestris and $P$. abies and is accompanied by a synchronous rise of Betula (up to $20 \%$ ), Alnus (up to $10 \%$ ) and Juniperus (up to $2 \%$ ). Among NAP, a high frequency of cultivated plants is registered, e.g. S. cereale (up to $8 \%$ ), Triticum-type (up to $8 \%$ ) and Cannabis/Humulus (up to $1 \%$ ). The group of ruderals and weeds reaches the highest representation in the entire profile, the same as grasslands representatives (e.g. Poaceae up to $16 \%$, Cyperaceae up to $5 \%$, Rumex acetosa-type, Plantago lanceolata-type and Ranunculus). The lowest PARs of AP are found in $\mathrm{AD} 1820$ and between $\mathrm{AD} 1865$ and 1910 (mean values of 15,000 pollen grains $\mathrm{cm}^{-2}$ year $^{-1}$, Fig. 5). High NAP influx is observed especially in the period $\mathrm{AD}$ 1810-1880 and from AD 1920 onwards. ChARs are highest between $\mathrm{AD} 1810$ and 1850 when their mean value is 14,500 particles $\mathrm{cm}^{-2}$ year ${ }^{-1}$ and between AD 1920 and 1940 , with values of ca 7,800 particles $\mathrm{cm}^{-2}$ year $^{-1}$.

The characteristic feature of the sixth zone (L PAZ LZ 6; Betula-Alnus; AD 1950-2010) is the decreasing tendency of herbs accompanied by a partial restoration of woodlands as manifested for example by the rise of Betula pollen (up to $35 \%$ ). Since AD 1970, an increase in Alnus pollen is observed (up to $30 \%$ in $\mathrm{AD}$ 2000). P. sylvestris pollen 
reaches 22-37\%. Secale cereale and Triticum-type decrease after $\mathrm{AD} 1950$ while Rumex acetosella-type (up to $7.4 \%$; AD 1950) and Artemisia pollen (up to $5 \%$; AD 1955) reach maximum values. PARs of AP increase up to 30,000 pollen grains $\mathrm{cm}^{-2}$ year $^{-1}$ on average, while PARs of NAP decrease from ca 12,000 to 5,000 pollen grains $\mathrm{cm}^{-2}$ year $^{-1}$ in the 1990s. The charcoal influx is low (ca 8100-2,200 particles $\mathrm{cm}^{-2}$ year $^{-1}$ ).

Our results demonstrate that the most important vegetation change from forested to a partly open landscape took place between $\mathrm{AD} 1590$ and 1610. At this time, non-forest communities became significant, and permanent deforestation of large areas in the lake region started. Charcoal accumulation rates (Fig. 4) reveal several maxima: $\mathrm{AD}$ 1610-1640, AD 1790-1860 and AD 1900-1970. A generally higher representation of charred particles was registered after strong deforestation of the area, but the larger fraction of microcharcoal $(>100 \mu \mathrm{m})$ indicative of local fires was already regularly registered between AD 1060 and 1290, i.e. prior to the time of the Teutonic Order.

\section{Sedimentation rate and geochemical composition}

Varve thickness and sedimentation rates in Lake Żabińskie were relatively low and stable from the beginning of the last millennium until ca $\mathrm{AD} 1600$ (Fig. 4). Thereafter, a slight increase in sedimentation rates is recorded until ca $\mathrm{AD}$ 1720 when a marked shift to higher values occurred. The period AD 1750-1850 is characterised by maximum values of varve thickness and highest variability. After a gradual decrease, the next maximum in sedimentation rates is recorded between $\mathrm{AD} 1960$ and 1980, followed by decreasing rates until recent times.

$\mathrm{Ti}$ values correlate positively with sedimentation rates. Low and stable values were recorded until ca AD 1720; then, a substantial increase occurred until the late 1950s when values dropped again. Biogenic silica contents were low and stable until ca AD 1680 (between 10 and $20 \%$ ) and rapidly increased to $>30 \%$ thereafter. High contents of BSi are recorded in the sediments until ca AD 1930; subsequently BSi concentrations decreased strongly to minimum values in recent years. Fe/Mn ratios show high values until ca AD 1620. In the following period until ca AD 1850, $\mathrm{Fe} / \mathrm{Mn}$ values decreased gradually and reached minima from the second half of the 19th century onwards.

\section{Interpretation and discussion}

As the pollen sequence from Lake Żabińskie is the first one in the region with a sub-decadal resolution, we attempted to correlate historical documentary information with vegetation changes registered in our pollen record. We focused on one hand on historical events which could have affected the size of local populations (such as warfare, famine, plagues) and, on the other hand, on climate data (periods of unfavourable climatic conditions, extremely cold winters etc.). Due to the lack of written sources for the time prior to the conquest of Prussian territories by the Teutonic Order the cross-correlation with historical data was restricted to the last six centuries.

\section{The history of environmental changes}

During the last millennium the vegetation history of the Lake Żabińskie area shows five stages of major changes (Figs. 3, 4 and 5).

\section{Stage 1 (L PAZ 1 and 2), AD 1000-1440; domination of forests with slight anthropogenic transformation}

Prior to the Teutonic Order crusade, the studied area belonged to the Prussian tribal territory called Galindia, located not far from the border of Sudovia to the east and Nadrovia to the north (Biskup et al. 2008; Pluskowski 2013). Around AD 1000, different types of forests slightly disturbed by humans occurred in the surroundings of Lake Żabińskie. Woodland communities with pine and birch as the main forest forming trees (with possible admixtures of spruce) predominated on less fertile and sandier soils. Most probably, forests had the character of the PeucedanoPinetum, Molinio-Pinetum or Vaccinio uliginosi-Pinetum (Polakowski 1961; Siuta 1994) which are the associations growing now in the area. Birch grew in different woods of pine and mixed pine forests and various carrs. As a pioneer species birch could occur in disturbed forest stands as well as in wet places or peat bogs where it formed communities similar to the modern sub-boreal pine-birch swamp woodlands (Thelypteridi-Betuletum pubescentis; Matuszkiewicz 2005). In oak-hornbeam forests (Tilio-Carpinetum), the emergent layer was probably formed by Quercus robur, Tilia cordata, Acer platanoides and Ulmus, the lower canopy layer by Carpinus betulus, while Corylus avellana was a component of the understorey. At the present time, such forest types are widespread in the large forest complexes of the Puszcza Borecka Forest (Fig. 1; Polakowski 1961, 1963) and the Puszcza Romnicka Forest (located ca $35 \mathrm{~km}$ northeast of Lake Żabińskie) (Hołdyński and Dynowski 2013). The increased frequency of Quercus and $C$. betulus pollen around AD 1106-1210 indicates the spread of these trees in local oak-hornbeam forests. The synchronous decrease of birch frequency around AD 1100 could have been caused by increasing competition from shade-tolerating species. Alder woods and carrs with Alnus, Fraxinus, Populus, Salix, Betula and Ulmus were present in 
wet habitats near the lake and along water courses. Alder woods (Carici elongatae-Alnetum) gained in importance between ca $\mathrm{AD} 1200$ and 1260. The expansion of Picea abies since $\mathrm{AD} 1350$ reflects the development of forests with spruce. Most probably these woods resembled modern forest associations occurring today in the Puszcza Borecka Forest: Calamagrosti-Piceetum, Sambuco racemosi-Piceetum, Querco-Piceetum and Sphagno-Piceetum (Polakowski 1961, 1963).

As the pollen spectra were characterized by the high proportion of arboreal pollen ca $95 \%$, which is similar to the modern results obtained in old forest stands of the Białowieża National Park (Baker et al. 2016), we assume that the lake vicinity was dominated by forest communities. Stage 1 was also a period of the highest PARs of arboreal pollen reaching up to 64,000 pollen grains $\mathrm{cm}^{-2}$ year ${ }^{-1}$. An interesting phenomenon is the regular presence of beech pollen. Since the study area is located beyond the present-day natural range of Fagus sylvatica, the question about the occurrence of beech stands arises. For the first time, pollen flux data with 3-years resolution from Lake Żabińskie offer the possibility of reconstructing annual pollen deposition of Fagus in this region and to interpret the fossil data in relation to modern observations (Fig. 5). The modern data from northern Poland show that when small patches of beech dominated forests were present within $2 \mathrm{~km}$ distance from pollen traps, Fagus PARs varied between 558 (the distance to trees 20-30 m; Kashubian Lakeland) and 165 pollen grains $\mathrm{cm}^{-2}$ year $^{-1}$ (the distance to trees 400-1700 m; Brodnica Lakeland; Pidek et al. 2010). PARs of Fagus recorded in Lake Żabińskie sediments were generally low, but in a few samples they reached up to 480 and 610 pollen grains $\mathrm{cm}^{-2}$ year $^{-1}$ (around $\mathrm{AD} 1130$ and 1290 respectively), suggesting that scattered beech trees were present in the region (Fig. 5).

The high proportion of pollen of shade-intolerant pine and light-demanding birch suggests that local forests were not very closed. This phenomenon was confirmed on different sites by the application of pollen based models such as the Regional Estimates of VEgetation Abundance from Large Sites (REVEALS; Sugita 2007a), Local Vegetation Estimates (LOVE; Sugita 2007b) and Landscape Reconstruction Algorithm (LRA; Sugita 2007a, b: Gaillard et al. 2010; Hultberg et al. 2015).

The disturbances of local woodlands, which were minor in pre-Teutonic Order times, became slightly stronger after the conquest in the second half of the 13th c. AD. The low representation of cereals documents their cultivation and suggests that small fields were located near the lake, but not necessarily in the direct vicinity of its shore. The regular presence of grassland taxa and general open land indicators such as Poaceae, Plantago lanceolata (since $\mathrm{AD}$ 1010), Rumex acetosa (since AD 1090) and Cichorioideae suggests the occurrence of open areas near the lake. These were possibly used for grazing. The recent PARs showed that pollen productivity values obtained from the closecanopy old-growth forest differ from those obtained in cultural landscapes and confirm strong under-representation of non-arboreal pollen (Baker et al. 2016). According to the REVEALS the pollen percentages of Poaceae, Cerealia, Rumex and Plantago lanceolata are lower than the mean estimated vegetation cover (e.g. Gaillard et al. 2010; Hultberg et al. 2015; Trondman et al. 2015). Between AD 1065 and 1290 the regularly occurring charcoal microparticles (Fig. 4) as well as the high proportion of Betula (Fig. 3) indicate regional and some local wildfires but also the use of fire by Galindians as an agricultural practice for field manuring and/or for clearing the ground for cultivation (Wacnik et al. 2014).

Although the climatic conditions during the MCA were favourable for supporting the development of agriculture in the Baltic regions (e.g. Stančikaite et al. 2009; Stivrins et al. 2015a) agricultural activities in the Lake Zabińskie area were still rather weak. This is in contrast to other places in the same region e.g. in the vicinity of Lakes Wojnowo and Miłkowskie, (Fig. 6) that were already heavily deforested and used by the Prussian population from the 12th century AD onwards (Wacnik et al. 2012, 2014). In the area of Lake Żabińskie human indicators have appeared regularly since $\mathrm{AD} 1000$, although only much later (around AD 1360; Fig. 6) at noticeable levels, when this area became part of the Monastic State of the Teutonic Order for several decades. During this time, however, human impact remained low and did not cause substantial changes in the sedimentation rates and the chemical composition of the sediments. Indicators of erosion in the catchment $(\mathrm{Ti})$ and in-lake production $(\mathrm{BSi})$ remained at low levels and did not show substantial variability (Fig. 4). The high Fe/Mn ratio indicates (seasonally) anoxic conditions at the lake bottom due to lake stratification during summer, which could have been favoured by the dense forest cover around the lake reducing wind-induced water column mixing.

\section{Stage 2 (L PAZ 3), AD 1440-1610; greater disturbances of woodlands; crop fields at some distance away from the lake}

The arrival of German and Masovian settlers is related to the last colonization campaign of the Teutonic Order which took place in the north-eastern regions of the Puszcza Galindzka Forest in the period AD 1460-1525 (Biskup et al. 2008; Toeppen 1870). Historical information about 


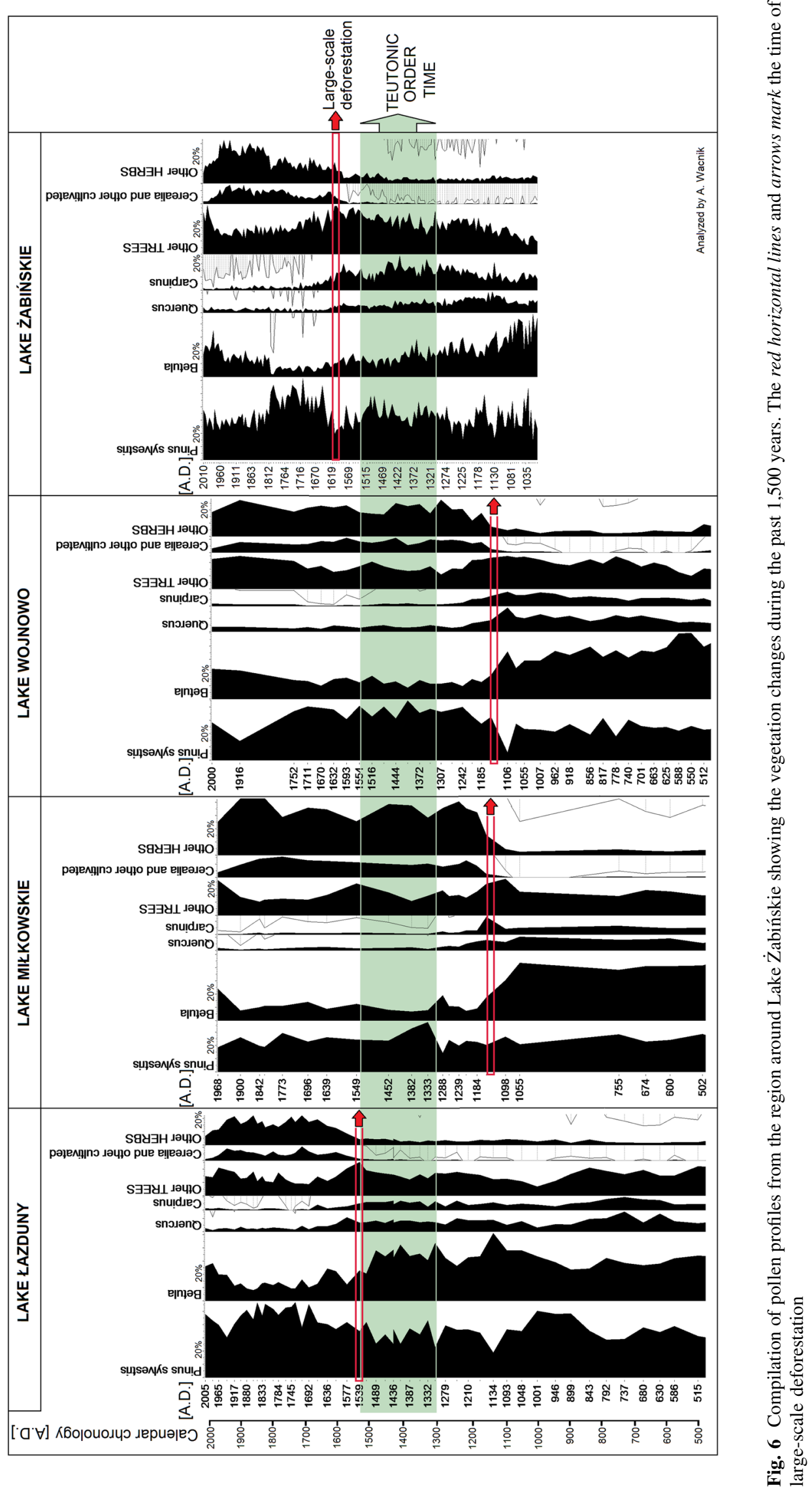


granting permissions for continuation of tar, birch tar, ash and charcoal production in the northern and south-eastern regions of the "Great Forest" indicates the persistence of a dense forest cover in these areas (Białuński 1996; Biskup et al. 2008). Pollen data from Lake Żabińskie suggest the start of more intense agriculture in an environment that was still strongly forested ca AD 1445-1460 (Figs. 3 and 4). Our observations confirm that local forests were subject to thinning at that time. Temporary vegetation changes coincided with the distinct shift from shorter to longer winters recorded in Lake Żabińskie ca AD 1430-1460 during the Spörer Minimum (Hernández-Almeida et al. 2015).

Decreases of Quercus pollen frequencies after AD 1440, declining Carpinus betulus in the period AD 1465-1520 and reduced Picea abies (ca AD 1450-1470) could reflect more extensive temporary forest clearances. However, these were not clear cuts of large areas but were rather related to selective search for timber and clearing of small patches for agricultural purposes. It seems that anthropogenic disturbances at the time of the decline of the Teutonic Order impacted mostly oak-hornbeam and mixed pine forests. The first half of the 15th century AD was the culmination phase of timber trade coming from Teutonic Prussia (Więcko 1979). Historical data indicate that wood of deciduous trees, Taxus and Larix was exploited in the first place (Jutrzenka-Trzebiatowski 1999). Pollen data showed that since ca $\mathrm{AD} 1470$ Picea abies regained its significance in the local forests. In places that were cleared and exploited by the local population, patches of hazel-spruce (Corylo-Piceetum) forest could develop. These forests were rich in Betula, Populus tremula, Carpinus betulus and Quercus and understorey, and resemble those types that are currently present nearby Lake Łękuk in the Puszcza Borecka Forest (Siuta 1994). The frequency of human indicators around AD 1465-1530 and the appearance of new weed taxa (Scleranthus, Spergula arvensis, Polygonum aviculare) suggest slightly increasing agricultural activities in the Lake Żabińskie region (Figs. 3 and 4). Cereals were the main crops but hemp, hop and buckwheat were also cultivated. The presence of microcharcoal particles (with an episode of higher concentration and large particle fraction) suggests fires (wildfire and/or anthropogenic fires) around the lake, especially between ca AD 1480 and 1504 .

When Ducal Prussia was created, a short-lasting forest regeneration took place at ca $\mathrm{AD} 1530-1580$. This was probably due to a population decrease caused by repeated epidemics in AD 1529, 1549 and 1559 (Achremczyk 2010a; Toeppen 1870).

According to historical documents a local settlement network developed as early as in the second half of the 16th century with the establishment of the villages Kruklanki
(AD 1545), Przerwanki (AD 1549), Kuty (AD 1560), Brożówka and Jakunówko (AD 1562) and Jeziorowskie (AD 1570 ) in the surroundings of Lakes Żabińskie and Gołdopiwo (Białuński 2002) (Fig. 7). Economic development and intensification of cereal trade is reported for that time (Małłek 1967). However, no evidence of intensive use of fire was found. Larger microcharcoal particles indicating local fires were recorded ca AD 1580 and 1600 when the frequency of cultivated plants increased again. From the middle of the 16th century AD onwards, the Weqgorzewo region was used for metallurgy and iron smelting which caused an increasing demand for hardwood (Toeppen 1870). Sedimentological and geochemical indicators still did not show any changes related to the slight increase in human impacts.

The major land cover transformation from wooded to a strongly open landscape with extensive farmland took only ca 20 years between AD 1590 and AD 1610 (Figs. 3 and 4). The permanent deforestation of large surfaces was a result of constantly increasing human activities. Undoubtedly, this was associated with the stabilization of local settlements and the establishment of fields and meadows in the

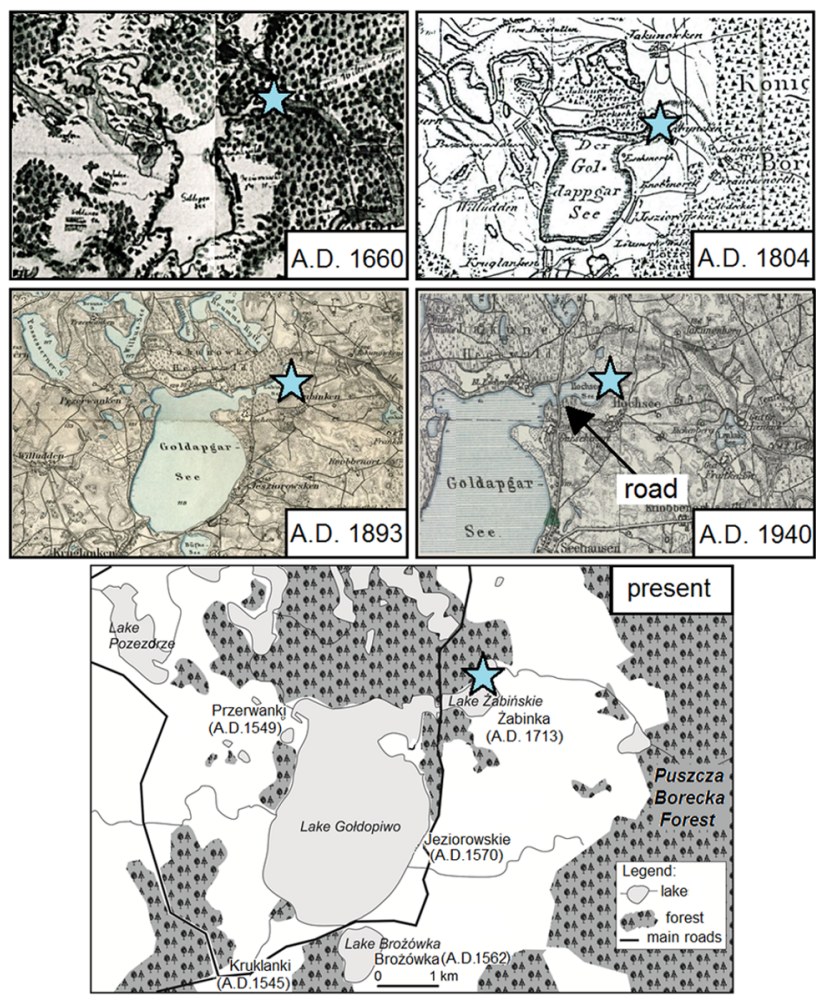

Fig. 7 Changes of forest extent in the Lake Żabińskie area (indicated by a star) registered on historical maps from ca AD 1660, AD 1804, AD 1894, and AD 1940 (the road separating Lake Gołdopiwo from Lake Żabińskie is shown) with reference to the current distribution of woodlands in the area and the location of the villages. The years of establishment of the villages are marked in brackets 
immediate vicinity of Lakes Gołdopiwo and Żabińskie. Interestingly, these intense forest clearances as recorded in the pollen diagram took place about 20-30 years after the establishment of the villages Brożówka and Jakunówko ( $\mathrm{AD}$ 1562), and Jeziorowskie (AD 1570) in the vicinity of Lake Gołdopiwo, not far from Lake Żabińskie (Białuński 2002). Increasing demands by the local society enlarged the area used for wood and farm land (Fig. 7).

\section{Stage 3 (L PAZ 4), AD 1610-1810; increased deforestation; stabilization of settlements and establishment of fields near the lake}

The pollen record reveals rapid destruction of the lime-oakhornbeam forest and alder woods on the lake shore after $\mathrm{AD}$ 1610. In the following period woods dominated by Pinus sylvestris and Picea became most common in the region. The area around the lake was mostly and permanently deforested. High percentage values of $P$. sylvestris pollen, in parallel with the marked reduction of its PARs, most probably reflect pollen transport from a distance. The first hand-written map of the Prussian territories from ca $\mathrm{AD}$ 1660 by N. Naroński contains information about the distribution of forest communities (Szeliga 1997). It shows a great forest complex east of Lake Żabińskie and fairly forested shores, which is in contrast to the almost completely deforested surroundings of Lake Gołdopiwo (Fig. 7). This confirms that our palynological results illustrate rather regional phenomena occurring at a distance of a few tens of kilometres from our coring site. As suggested by the pollen record, open habitats were used for cereal, buckwheat, hemp and/or hop and flax cultivation. The increase of agriculture between AD 1615 and 1640 is marked by consistently high representation of Secale cereale and Triticum. The cultivation of Cannabis sativa, Humulus lupulus and Linum usitatissimum is also confirmed by historical records from the beginning of the 17th century documented by a brewery near Weqgorzewo and the mandatory supply of flax and hemp cloth and yarn for the Elector (ruler of Prussia) (Toeppen 1870). In AD 1617, the village of Możdżany was founded a few kilometres from Lake Żabińskie in the region of the Puszcza Borecka Forest. Increased economic activities between AD 1613 and 1640 are also suggested by slightly higher charcoal accumulation rates. From AD 1660 onward, our pollen record shows a decrease in cultivated plants and an increase in ruderals and weeds, particularly of Rumex acetosella and Artemisia, but also Chenopodiaceae and Polygonum aviculare. This indicates the reduction of farming possibly caused by a population decrease (Kossert 2009). According to M. Toeppen (1870), former Galindia was heavily devastated by military operations during the "Swedish deluge" and after the Tatarian-Lithuanian invasions (AD 1656-1657) when "half of the land lay fallow for 10 years".

Climate cooling during the Maunder Minimum (AD 1645-1715; Eddy 1976) could have favoured the spread of spruce as observed in our record in the period $\mathrm{AD}$ 1658-1707. However, according to Hernández-Almeida et al. (2015) the winter climate data from Lake Żabińskie do not show evidence that this was a particularly cold phase as reported in several western European paleoclimate records. A very severe winter and the disaster of a bad year in $\mathrm{AD} 1709$ as well as the significant depopulation after the catastrophic plague epidemic in AD 1709-1711 are not unequivocally reflected in our pollen record. However, documentary data suggest that the "Great Plague", intensified by the general poverty in East Prussia, directly affected the areas of Kuta, Weqgorzewo, Kruklanki and Giżycko for example (Kossert 2009; Toeppen 1870).

After AD 1610, a substantial increase in human impact was registered by changes in sedimentological and geochemical indicators. A first increase in varve thickness was recorded at the beginning of this period. Around AD 1680, biogenic silica increased indicating higher productivity of the lake. Another rise in the sedimentation rates occurred shortly after the foundation of Żabinka village (ca AD 1720). In the following period sedimentation rates reached their maximum at the end of the 18th century. This increase was related to enhanced erosion in the deforested catchment as suggested by higher Ti contents in the sediments beginning from ca AD 1720 onward. Since ca AD 1620, a significant change in redox conditions is also observed. The $\mathrm{Fe} / \mathrm{Mn}$ ratio indicates a gradual shift from at least seasonally anoxic conditions to better oxygenation of the deep waters of Lake Żabińskie. This might have been related to deforestation and landscape opening with better wind fetch and thus better mixing of the water column.

\section{Stage 4 (L PAZ 5), AD 1810-1950; widely open area with patches of woods; the most intensive agriculture}

The next significant environmental changes started during Napoleon's campaigns at the beginning of the 19th century (Figs. 3 and 4). According to Büntgen et al. (2013) the coldest decades occurred between AD 1808 and 1837. Around AD 1810, pollen data revealed an episode of fast destruction of spruce and pine woods in the lake surroundings. In response to the deforestation, an extensive Betula spread began. Birch formed vicarious communities on disturbed habitats and on fallow fields. On the abandoned moist meadows, alder could accompany birch. Fairly numerous juniper shrubs developed on pastures and 
in open pine forests where they formed a transitional stage in the plant succession. The higher frequency of juniper from Medieval times is a known phenomenon in northern Poland (e.g. Madeja 2013; Madeja et al. 2010; Okuniewska-Nowaczyk et al. 2004; Pawlikowski et al. 1982; Ralska-Jasiewiczowa 1966). After AD 1810, a strong development of herbaceous plants took place, particularly of ruderals, weeds and general open-land indicators. The extended deforestation coincided with prolonged winters as observed in the studied area around AD 1800-1820 (Hernández-Almeida et al. 2015). This period corresponded largely to the Dalton Minimum (AD 1795-1830; Eddy and Oeschger 1993) and a period with strong negative volcanic forcing (Hernández-Almeida et al. 2015). Unfavourable climatic conditions (frosty winters and wet summers) in the region were also recorded in written sources (Toeppen 1870). Crop failures conditioned by bad weather followed by several cholera epidemics (since AD 1831) contributed to serious population losses. These phenomena do not seem to have affected the local vegetation. Furthermore, vegetation changes suggest increasing human activities. Vast surfaces were transformed into fields, which were mainly used for cultivation of cereals and Fagopyrum, and meadows. This is suggested by higher taxonomic diversity and maximum values for herb pollen, especially for Poaceae, Cyperaceae, Plantago lanceolata, Rumex acetosa, and Ranunculus (Fig. 4). The sustained high frequency of farming indicators confirms the existence of arable land and meadows in the direct vicinity of the lake. Among the cereals, rye is adapted to grow on sandy soils and was better represented especially from ca AD 1860. High infestation of fields with Rumex acetosella increased from $\mathrm{AD} 1810$, which may indicate that poorer soils were put under cultivation or that soil degradation proceeded (Miotk-Szpiganowicz et al. 2004 and references therein).

High charcoal fluxes (AD 1785-1850) indicate enhanced use of fire during this cold period. According to Toeppen (1870), the year AD 1867 was extremely bad due to prolonged rains. This caused the emigration of a part of the population. In the pollen record this climatic event is evidenced by the lowest PARs in the sample dated to AD 1870 (Fig. 5).

The 19th century $\mathrm{AD}$ was the time of intensive land reclamation and the construction of canals between lakes, which caused water level lowering (Karczewski 2008; Toeppen 1870). Such works were carried out across the territory of the whole of Prussia in order to improve the navigability of lakes and rivers, and to enlarge the surface of arable fields and meadows. For instance, Lake Gołdopiwo was connected by a canal to Lake Kruklin in $\mathrm{AD}$ 1841-1842, which caused a water level lowering in the latter and provided additional areas for agriculture. In $\mathrm{AD}$ 1836, shallow Lake Staświńskie and, in $\mathrm{AD} 1865$, the
Nietlice marshes (Fig. 1) were drained and a vast area of meadows formed in the region (Toeppen 1870). Similar activities were registered in Lake Żabińskie in $\mathrm{AD}$ 1836-1878. Other pollen sequences from the region (Wacnik et al. 2012) recorded increased frequencies of general open land taxa, particularly Poaceae and Cyperaceae. The human activities in East Prussia led to wide deforestation at the end of the 19th century $\mathrm{AD}$ when an average proportion of forest cover in the area reached ca $17.4 \%$ (Jutrzenka-Trzebiatowski 1999). According to our data, particularly intensive agricultural activities took place between $\mathrm{AD} 1870$ and 1910 and then between $\mathrm{AD} 1930$ and 1940. The heavy fighting in the region during World War I caused enormous material losses (destruction of infrastructure) and the flight of the population. In our pollen record, the reduction of cultivated taxa is visible. The interwar period was a time of flourishing agriculture, which is reflected by a high frequency of cereals. Since ca AD 1945 when the fields were abandoned, the reduction of crop cultivation was accompanied by an intensive expansion of ruderals, weeds and other herbs on fallow lands. Evacuations, fighting, and deportations of people from Masuria (the historical province which occupies much of the Masurian Lake District) during the winter AD 1944/1945 as well as the massive emigration of the inhabitants of Prussia caused the depopulation of these areas and the decrease of agricultural activities.

These changes in the lake catchment are recorded in highly variable sedimentation rates, high erosion in the catchment and high lake productivity. After a maximum pulse in AD 1830-1850, erosion started to decrease gradually, but the delivery of minerogenic material from the catchment was still relatively high. In the lake, primary production was more or less stable as suggested by relatively constant BSi contents in the sediments. The open landscape provided conditions favourable for intensive wind mixing of the water column; thus the $\mathrm{Fe} / \mathrm{Mn}$ ratios dropped to minimum values. This indicates oxic conditions in the hypolimnion of the lake.

\section{Stage 5 (L PAZ 6), AD 1950-2010; the decrease of agricultural activities and reforestation}

Since AD 1950, intensified development of fast growing pioneer trees and shrubs was observed in the region of Lake Żabińskie, indicating spontaneous afforestation of the abandoned agricultural lands. This process has intensified after AD 1965 (Fig. 5). Palynological results suggest that, in the 1960s, the structure of local cultivation had changed and growing of some plants had ceased, e.g. of Fagopyrum, and a decade later also of Cannabis/Humulus. This was primarily the time of significant changes in agrarian 
techniques related to the introduction of artificial fertilizers, herbicides and heavy machinery during the 1960s/70s. The last decades of the 20th century were also the time when new varieties of autogamous cereals were introduced; field infestation with weeds decreased and changes in segetal flora took place (Kornaś 1987; Korniak 1992; Ługowska 2014). The decrease of palynological richness, decreasing frequency of anthropogenic indicators and charcoal are registered in the Lake Żabińskie sediments (Fig. 4). Additionally, erosion in the catchment decreased substantially, which is visible in the titanium record. Sedimentation rates reached maximum values during the late 1970s simultaneously with the peak in BSi content, which suggests enhanced primary production. Since the 1980s both the sedimentation rates and the lake production have decreased. Interestingly, together with reforestation, the $\mathrm{Fe} /$ $\mathrm{Mn}$ ratio values started to increase again. This might be due to better protection of the lake against wind, reduced water column mixing and enhanced anoxic conditions. This is confirmed by limnological measurements showing long periods of anoxia in the hypolimnion of Lake Zabińskie (Bonk et al. 2015a).

\section{Relevance of the Teutonic Order activity to the large-scale deforestations in the Great Masurian Lake District}

Comparative analyses of pollen sequences from the whole region showed large spatial-temporal differences in woodland exploitation in the Great Masurian Lake District area (Fig. 6). The beginning of large-scale woodland clearings occurred in some areas as early as between the 11 th and 12th centuries AD. The surroundings of Lakes Wojnowo and Miłkowskie, situated in the area of intensive settlement around Staświny may be used as an example (Karczewska and Karczewski 2007; Karczewski 2006, 2008). As in the case of Lake Salęt in the Mraggowo Lake District, deforestation was likely related to the settlement centre of the Galindian tribe (Szal et al. 2014; Wacnik et al. 2014). Due to colonization campaigns during the period of the Teutonic Order, the whole region experienced an intensive growth of settlement networks, administrative and economic developments including timber trade and corn markets (Biskup et al. 2008; Pluskowski 2013). The influence of the Teutonic Order on the environment in Prussia and Livonia has been subject to several interdisciplinary studies carried out in recent years (e.g. Brown and Pluskowski 2011, 2013; Stivrins et al. 2015a, b; Wacnik et al. 2014). In the surroundings of Lake Łazduny, temporary disturbances of vegetation were recorded at times of the last colonization campaign of the Order (AD
1460-1525). This area was intensively cleared at the very end of the Order's activities in Prussia (Fig. 6). In contrast, Lake Żabińskie represents sites which remained forested until AD 1590 and 1610, i.e. the middle of the Ducal Prussia period. Comparative analysis of pollen profiles from different sites in the Masurian Lake District shows that late deforestations (after AD 1525) occurred to the east and north of Lakes Śniardwy and Mamry. Our data confirm the view that the process of permanent deforestation of vast areas in the Great Masurian Lake District cannot exclusively be attributed to the Crusaders' activities, despite the fact that the changes in forest resources caused by the Order's activities can be traced in almost every pollen sequence.

\section{Reforestation after World War II: recession of agriculture?}

According to the historical data, reforestation of the formerly arable land in Poland was most intensive in the years AD 1947-1987 and led to a significant rise in forested areas, particularly on terrain such as Masuria that were incorporated into Poland after World War II (Smykała 1990). This process is reflected also in the pollen record from Lake Żabińskie where the increased frequency of pioneer trees and shrubs is noted since $\mathrm{AD} 1950$ (Figs. 3 and 4). The interpretation of this phenomenon is not unequivocal. The increase of pollen frequency of fast-growing pioneer birches observed since 1948 reflects their extensive spread on lands where agricultural activities have ceased (e.g. Faliński 1997; Hynynen et al. 2010; Karlsson et al. 1998). In the successive years, the decline of PARs of human indicators was recorded synchronously with the expansion of birch, alder and willow. These changes provided evidence of the development of vicarious communities. Most likely, as it is now, the poor, moist and wet lands unfit for persistent reclamation and unprofitable for farming were let to lie fallow. Tree stands of such secondary woods were probably composed of even-aged Alnus with Betula pendula and Betula pubescens in admixtures. In the understorey, Sambucus nigra and Salix were growing among other plants as is observed today (Bijak et al. 2013). Additionally, alder expansion from the 1970s was enabled by the poor efficiency of local drainage causing the rise of ground water levels. This phenomenon can also be observed nowadays in the Great Masurian Lake District, for instance in the region of the Staświny Meadows.

The secondary succession from wet grasslands to alder carr dominated by Alnus glutinosa was recorded in different parts of Europe during the 20th century. The observations by Douda et al. (2009) revealed that the 
spread of such a forest in the Czech Republic predominated until the 1970s and the observed succession pathways at sites of alder carr were probably caused by local changes in the groundwater table.

The spontaneous natural reforestation has become more and more important as the area of abandoned lands has increased in response to socio-economic changes that took place not only in the studied region but in whole of Central and Eastern Europe at the end of the last century (Bijak et al. 2013; Młynkowiak and Kutyna 2009; Stanturf 2015; Zasada et al. 2014). Low-intensity afforestation relying upon natural recolonization of abandoned fields and pastures has proven to be effective under the growing conditions of the whole Baltic region. The light-seeded trees, alder together with birch, aspen and willows, could form tree layers in the course of a dozen years or so (Bomanowska and Adamowski 2009; Faliński 1997). During the last decades and following independence from the Soviet Union, large areas of agricultural land in Estonia, Latvia and Lithuania were abandoned and underwent oldfield succession (Stanturf 2015). In the area of the Great Masurian Lake District, reforestation has intensified again in the 1990s when, in consequence of the political and economic transformation, state farms disappeared and land property rules were changed. This process was recorded in a regional pollen sequence from Lake Czarne (KarpińskaKołaczek et al. 2014).

Palynological results obtained from Estonia are quite similar to our observations from Masuria and show that human impact favoured the early-successional trees that can colonize abandoned fields or can grow on less fertile soils (Poska et al. 2004). Analogous phenomena were described also from northeastern Germany. Theuerkauf et al. (2015) showed that non-arboreal pollen deposition sharply declined over the last 90 years, although the land use statistics show that vegetation openness remained largely constant. They suggested that the decline of herb pollen deposition can be partly explained by a shift towards cultivation of crops that shed less pollen, such as wheat and oilseed rape. Moreover, grass pollen productivity decreased (by about $60 \%$ ) as a result of earlier and more frequent mowing.

In summary, the vegetation changes that took place in the last decades on the territory of the Great Masurian Lake District were a combined result of several co-existing factors, particularly of the radical change of land-use practices caused by the political and economic changes. Several factors which may disturb the estimation of open communities in the landscape should be taken into consideration. For instance, (1) lower pollen production of cultivated plants due to the introduction of self-pollinated varieties (wheat, rye, triticale) mask changes in the acreage of the arable land; (2) the application of herbicides eliminates some weed species and modifies the composition of segetal communities; (3) reduced crop rotation and the introduction of new tillage techniques (use of combines for harvesting cereals and pressing straw in bricks, by protecting hay in bales and cut grass in plastic foil with their assignment for forage) cause the limitation of pollen dispersal.

\section{Conclusions}

Palynological studies of annually laminated sediments from Lake Żabińskie in northeastern Poland provide a detailed high-resolution (6 years) record of vegetation and land-use changes during the last millennium. The changes of forms and intensity of land use which occurred during that time altered the natural environment of the region. Here, we attempted to reveal through pollen and geochemical data, which processes/phenomena had significant impacts on the landscape. The main results can be summarized as follows:

- In the pre-Christian period (before ca AD 1300), the Galindian tribe caused temporary disturbances of local forests, and agricultural activities were conducted at a distance from the lake in a heavily forested environment.

- The influence of the Teutonic Order economy on local vegetation is confirmed since ca $A D$ 1360. From the second half of the 15th century AD (ca AD 1460) onward, impacts on vegetation became much stronger.

- Co-domination of pine forests with spruce and oakhornbeam forests on drier habitats as well as the presence of birch and alder woods on wet surfaces near the lake lasted until AD 1610. The distinct change from the densely forested to partly open environment with high proportions of agrocenoses and semi-natural woods occurred at the turn from the 16th to the 17 th century $\mathrm{AD}$. At this time, the nearby villages already existed but not directly on the lake shore. The process of deforestation was fast and lasted ca 20 years (ca AD 1590-1610). The distinct increase in sedimentary charcoal was related to the more intensive settlement and forest exploitation.

- Between AD 1610 and 1810, pine-spruce forest was the most important woodland community in the area.

- The most intense agricultural activities are dated to $\mathrm{AD}$ 1810-1940. Continuous exploitation of soils caused their degradation and acidification, which for example is manifested by the common cultivation of rye and expansion of Rumex acetosella.

- Our data confirm significant spatial-temporal differences in the initiation of large scale woodland clearings 
in Masuria. The general tendency was that the areas east of the Great Masurian Lakes (eastern Galindia and Sudovia territories) stayed forested much longer than those lying westwards.

- In several cases, the detailed varve chronology enabled the correlation of vegetation changes registered by pollen with data provided by documentary sources about historical events and climate anomalies.

- The interesting phenomena of the reforestation and the decline of herbaceous plants since $\mathrm{AD} 1950$ were registered. Expansion of secondary woods with pioneer species such as Betula, Populus, Salix and, from the 1970s onward also Alnus, could be the consequence of changes of agrarian techniques and land-use practices, post-war demographic changes, and the downfall of local state farms in the last decades.

Acknowledgments This research was supported by a grant from Switzerland through the Swiss Contribution to the enlarged European Union, Project CLIMPOL (PSPB-086/2010). The authors wish to thank Małgorzata Latałowa (University of Gdańsk) for botanical identification of plant macrofossils, Dorota Nalepka (W. Szafer Institute of Botany PAS, Kraków) and Adam Walanus (AGH University of Science and Technology, Kraków) for help in data processing, and Katarzyna Cywa (W. Szafer Institute of Botany PAS, Kraków) for technical assistance and laboratory preparation of pollen samples. We are indebted to Krystyna Wasylikowa (W. Szafer Institute of Botany PAS, Kraków) for comments and improvements to the paper.

Open Access This article is distributed under the terms of the Creative Commons Attribution 4.0 International License (http://crea tivecommons.org/licenses/by/4.0/), which permits unrestricted use, distribution, and reproduction in any medium, provided you give appropriate credit to the original author(s) and the source, provide a link to the Creative Commons license, and indicate if changes were made.

\section{References}

Achremczyk S (2010a) Historia Warmii i Mazur. Tom 1: Pradzieje 1772. Towarzystwo Naukowe i Ośrodek Badań Naukowych im. Wojciecha Kętrzyńskiego w Olsztynie, Olsztyn

Achremczyk S (2010b) Historia Warmii i Mazur. Tom 2: 1772-2010. Towarzystwo Naukowe i Ośrodek Badań Naukowych im. Wojciecha Kętrzyńskiego w Olsztynie, Olsztyn

Alliksaar T, Heinsalu A, Saarse L, Salujõe J, Veski S (2005) A 700-year decadal scale record of lake response to catchment land use from annually laminated lake sediments in southern Estonia. Verh Int Ver Theoret Angew Limnol 29:457-460

Anderson NJ, Odgaard BV, Segerström U, Renberg I (1996) Climatelake interactions recorded in varved sediments from a Swedish boreal forest lake. Glob Chang Biol 2:399-405

Baker AG, Zimny M, Keczyński A, Bhagwat SA, Willis KJ, Latałowa M (2016) Pollen productivity estimates from old-growth forest strongly differ from those obtained in cultural landscapes: evidence from the Białowieża National Park, Poland. Holocene 26:80-92

Bednarek R, Prusinkiewicz Z (1999) Geografia gleb. Wydawnictwo Naukowe PWN, Warszawa
Berglund BE, Ralska-Jasiewiczowa M (1986) Pollen analysis and pollen diagrams. In: Berglund BE (ed) Handbook of Holocene paleoecology and paleohydrology. Wiley, Chichester, pp 455-484

Beug H-J (2004) Leitfaden der Pollenbestimmung für Mitteleuropa und angrenzende Gebiete. Pfeil, München

Białuński G (1996) W sprawie lasów i leśnictwa w południowowschodnich Mazurach od XIV do początku XVIII wieku. Komunikaty Mazursko-Warmińskie 3(213):433-447

Białuński G (2002) Kolonizacja, Wielkiej Puszczy (do 1568 roku): starostwa piskie, ełckie, straduńskie, zelkowskie i węgoborskie (węgorzewskie), Rozprawy i Materiały Ośrodka Badań Naukowych im. W. Kętrzyńskiego w Olsztynie nr 159, Olsztyn

Bijak S, Zasada M, Bronisz A, Bronisz K, Czajkowski M, Ludwisiak Ł, Tomusiak R, Wojtan R (2013) Estimating coarse roots biomass in young silver birch stands on post-agricultural lands in central Poland. Silva Fenn 47(2):article id 963

Birks HH, Birks HJB (2006) Multiproxy studies in palaeolimnology. Veget Hist Archaeobot 15:235-251

Biskup M, Czaja R, Długokęcki W, Dygo M, Jóźwiak S, Radzimiński A, Mandecki J (eds) (2008) Państwo zakonu krzyżackiego w Prusach. Władza i społeczeństwo, Państwowe Wydawnictwo Naukowe PWN, Warszawa

Bomanowska A, Adamowski W (2009) The role of woody species in the secondary succession under monitored conditions (Bialowieża Forest, NE Poland). In: Ivanova D (ed) Plant, fungal and habitat diversity investigation and conservation. Proceedings of IV Balkan Botanical Congress, Sofia, 20-26 June 2006. Institute of Botany, Bulgarian Academy of Sciences, Sofia, pp 291-295

Bonk A, Tylmann W, Amann B, Enters D, Grosjean M (2015a) Modern limnology and varve-formation processes in Lake Żabińskie, northeastern Poland: comprehensive process studies as a key to understand the sediment record. J Limnol 74:358-370

Bonk A, Tylmann W, Goslar T, Wacnik A, Grosjean M (2015b) Comparing varve counting and 14C-AMS chronologies in the sediment of Lake Żabińskie, northeastern Poland: implications for accurate ${ }^{14} \mathrm{C}$ dating of lake sediments. Geochronometria 42:159-171

Briffa KR (2000) Annual climate variability in the Holocene: interpreting the message of ancient trees. Quat Sci Rev 19:87-105

Brown A, Pluskowski A (2011) Detecting the environmental impact of the Baltic Crusades on a late-medieval (13th-15th century) frontier landscape: palynological analysis from Malbork Castle and hinterland, Northern Poland. J Archaeol Sci 38:1,957-1,966

Brown A, Pluskowski A (2013) Medieval landscape transformation in the south-eastern and eastern Baltic: palaeoenvironmental perspectives on the colonization of frontier landscapes. Archaeologia Baltica 20:24-46

Buko A (2005) Archeologia Polski wczesnośredniowiecznej. Odkrycia: hipotezy-interpretacje. Wydawnictwo Trio, Warszaw

Büntgen U, Frank DC, Nievergelt D, Esper J (2006) Summer temperature variations in the European Alps, AD 755-2004. J Clim 19:5,606-5,623

Büntgen U, Kync T, Ginzler Ch, Jacks DS, Esper J, Tegel W, Heussner K-U, Kyncl J (2013) Filling the Eastern European gap in millennium-long temperature reconstructions. PNAS 110:1,773-1,778

Croudace IW, Rindby A, Rothwell R (2006) ITRAX: description and evaluation of a new multi-function X-ray cores canner. In: Rothwell RG (ed) New techniques in sediment core analysis. Geological Society Special Publication 267, London, pp 51-63

Davis MB, Deevey E (1964) Pollen accumulation rates: estimates from late-glacial sediment of Rogers Lake. Science $145: 1,293-1,295$ 
Douda J, Čejková A, Douda K, Kochánková J (2009) Development of alder carr after the abandonment of wet grasslands during the last 70 years. Ann For Sci 66:1-13. doi:10.1051/forest/2009065

Eddy JA (1976) The Maunder minimum. Science 18:1,189-1,202

Eddy JA, Oeschger H (1993) The role of solar output variations. In: Eddy JA, Oeschger H (eds) Global Changes in the Perspective of the Past: report of the Dahlem Workshop on Global Changes in the Perspective of the Past, Berlin 1991, December 8-13. Wiley, Chichester, pp 279-293

Enters D, Kirilova E, Lotter AF, Lücke A, Parplies J, Jahns S, Kuhn G, Zolitschka B (2010) Climate change and human impact at Sacrower See (NE Germany) during the past 13,000 years: a geochemical record. J Paleolimnol 43:719-737

Faliński JB (1997) Pioneer woody species and their role in the regeneration and secondary succession. In: Fałtynowicz W, Latałowa M, Szmeja J (eds) Dynamics and conservation of the Pomeranian vegetation. Bogucki Wyd. Nauk, Gdańsk-Poznań, pp 33-54

Gaillard M-J, Sugita S, Mazier F et al (2010) Holocene land-cover reconstructions for studies on land cover-climate feedbacks. Clim Past 6:483-499

Goslar T, van der Knaap WO, Kamenik C, van Leeuwen JFN (2009) Free-shape ${ }^{14} \mathrm{C}$ age-depth modelling of an intensively dated modern peat profile. J Quat Sci 24:481-499

Gotkiewicz J, Morze A, Piaścik H (1995) Rozmieszczenie i charakterystyka torfowisk i gytiowisk w Krainie Wielkich Jezior Mazurskich. Acta Academiae Agriculturae ac Technicae Olstenensis, Agricultura 60:25-34

Haas JN, Richoz I, Tinner W, Wick L (1998) Synchronous Holocene climatic oscillations recorded on the Swiss Plateau and at timberline in the Alps. Holocene 8:301-309

Haltia-Hovi E (2010) Holocene varved lake sediments as records of palaeoenvironmental change and geomagnetic palaeosecular variation in Eastern Finland. Annales Universitatis Turkuensis A II 251: Biologica-Geographica-Geologica. Academic Dissertations Turun Yliopisto University of Turku, pp 1-51

Hernández-Almeida I, Grosjean M, Przybylak R, Tylmann W (2015) A chrysophyte-based quantitative reconstruction of winter severity from varved lake sediments in NE Poland during the past millennium and its relationship to natural climate variability. Quat Sci Rev 122:74-88

Hołdyński Cz, Dynowski P (2013) Flora i roślinność Puszczy Romnickiej. In: Ciecierska H, Hołdyński Cz (eds) Dziedzictwo przyrodnicze Warmii, Mazur i Powiśla. Przewodnik do warsztatów terenowych 56. Zjazdu Polskiego Towarzystwa Botanicznego "Interdyscyplinarne i aplikacyjne znaczenie nauk botanicznych", Olsztyn, 24-30 czerwca 2013. Wydawnictwo Mantis, Olsztyn, pp 193-214

Hua Q, Barbetti M, Rakowski AZ (2013) Atmospheric radiocarbon for the period 1950-2010. Radiocarbon 55:2,059-2,072

Hultberg T, Gaillard M-J, Grundmann B et al (2015) Reconstruction of past landscape openness using the landscape reconstruction algorithm (LRA) applied on three local pollen sites in a southern Swedish biodiversity hotspot. Veget Hist Archaeobot 24:253-266

Hynynen J, Niemistö P, Viherä-Aarnio A, Brenner A, Hein S, Veling P (2010) Silviculture of birch (Betula pendula Roth and Betula pubescens Ehrh.) in northern Europe. Forestry 83:103-119

Jutrzenka-Trzebiatowski A (1999) Wpływ człowieka na szatę leśną Polski północno-wschodniej w ciągu dziejów. Rozprawy i Materiały Ośrodka Badań Naukowych im. Wojciecha Kętrzyńskiego, Olsztyn

Karczewska M, Karczewski M (2007) Grodzisko "Święta Góra" w Staświnach w Krainie Wielkich Jezior Mazurskich. Archeologia archiwalna i nowa, Komunikaty Mazursko-Warmińskie 2(256):131-163
Karczewski M (2006) Environment, settlement and economy of the West Baltic Tribes in the Roman Period. Key studies on two settlement microregions of Bogaczewo and Sudowska Cultures. Archaeologia Lithuana 7:54-65

Karczewski M (2008) Zmiany poziomu lustra wody w jeziorach mazurskich w ciągu ostatnich dwóch tysięcy lat w świetle źródeł archeologicznych i historycznych. In: Wacnik A, Madeyska E (eds) Polska północno-wschodnia w holocenie. Człowiek i jego środowisko. (Holocene of north-east Poland. Man and his environment). Botanical Guidebooks 30, Kraków, pp 47-75

Karlsson A, Albrektson A, Forsgren A, Svensson L (1998) An analysis of successful natural regeneration of downy and silver birch on abandoned farmland in Sweden. Silva Fennica 32(3), Article id 683. http://dx.doi.org/10.14214/sf.683

Karpińska-Kołaczek M, Kołaczek P, Stachowicz-Rybka R (2014) Pathways of woodland succession under low human impact during the last 13,000 years in northeastern Poland. Quat Int 328-329:196-212

Kerig T, Lechterbeck J (2004) Laminated sediments, human impact, and a multivariate approach: a case study in linking palynology and archaeology (Steisslingen, southwest Germany). Quat Int 113:19-39

Kinder M, Tylmann W, Ohlendorf C, Zolitschka B (2008) Laminowane osady denne jeziora Szurpily jako podstawa rekonstrukcji zmian środowiska przyrodniczego w północnowschodniej Polsce. In: Florek W, Kaczmarzyk J (eds) Współczesne problemy geomorfologii. Landform Analysis 9, Poznań, pp 241-246

Kondracki J (2002) Geografia regionalna Polski. PWN, Warszawa

Kornaś J (1987) Chwasty polne rozprzestrzeniane z materiałem siewnym. Specjalizacja ekologiczna i procesy wymierania. Zeszyty Naukowe AR Kraków 19:23-36

Korniak T (1992) Segetal flora of north-eastern Poland, its spatial differentiation and current changes. Acta Academiae Agriculturae Technicae Olstenensis, Agricultura 53(Suppl A):1-76

Kossert A (2009) Prusy Wschodnie. Historia i mit. Wydawnictwo Naukowe Scholar, Warszawa

Kubitz B (2000) Die holozäne Vegetations- und Siedlungsgeschichte in der Westeifel am Beispiel eines hochauflösenden Pollendiagramms aus dem Meerfelder Maar. Dissertationes Botanicae 339. Cramer, Berlin

Kupryjanowicz M (2008) Badania palinologiczne w Polsce północnowschodniej. In: Wacnik A, Madeyska E (eds) Polska północnowschodnia w holocenie. Człowiek i jego środowisko. Botanical Guidebooks 30, Kraków, pp 77-95

Leroy SAG, Zolitschka B, Negendank JFW, Seret G (2000) Palynological analyses in the laminated sediment of Lake Holzmaar (Eifel, Germany): duration of late glacial and Preboreal biozones. Boreas 29:52-71

Litt T, Brauer A, Goslar T, Merkt J, Bałaga K, Müller H, RalskaJasiewiczowa M, Stebich M, Negendank JFW (2001) Correlation and synchronisation of Lateglacial continental sequences in northern central Europe based on annually laminated lacustrine sediments. Quat Sci Rev 10:1,233-1,249

Lotter AF (1999) Late-glacial and Holocene vegetation history and dynamics as shown by pollen and plant macrofossil analyses in annually laminated sediments from Soppensee, central Switzerland. Veget Hist Archaeobot 8:165-184

Ługowska M (2014) Segetal flora of the Middle Vistula River Valley. Acta Agrobotanica 67:99-114

Madeja J (2013) Vegetation changes and human activity around Lake Łańskie (Olsztyn Lake District, NE Poland) from the mid Holocene, based on palynological study. Acta Palaeobot 53:235-261

Madeja J, Wacnik A, Wypasek E, Chandran A, Stankiewicz E (2010) Integrated palynological and molecular analyses of late 
Holocene deposits from Lake Milkowskie (NE Poland): verification of local human impact on environment. Quat Int 220:147-152

Małłek J (1967) Ustawa o rządzie (Regimentsnottel) Prus Książęcych $\mathrm{z}$ roku 1542: studium $\mathrm{z}$ dziejów przemian społecznych $\mathrm{i}$ politycznych w lennie pruskim. Roczniki Towarzystwa Naukowego w Toruniu 72:5-230

Matuszkiewicz W (2002) Przewodnik do oznaczania zbiorowisk roślinnych Polski. Wydawnictwo Naukowe PWN, Warszawa

Matuszkiewicz JM (2005) Przewodnik do oznaczania zbiorowisk roślinnych Polski. Wydawnictwo naukowe PWN, Warszawa

Matuszkiewicz JM (2008a) Potencjalna roślinność naturalna Polski IGiPZ PAN, Warszawa http://www.igipz.pan.pl/Roslinnoscpotencjalna-zgik.html. Accessed 17 Sept 2015

Matuszkiewicz JM (2008b) Zespoły leśne Polski. Wydawnictwo Naukowe PWN, Warszawa

Miotk-Szpiganowicz G, Zachowicz J, Harmata K, Madeja J, Nalepka D (2004) Rumex L.-Sorrels and docks. In: Ralska-Jasiewiczowa M, Latałowa M, Wasylikowa K, Tobolski K, Madeyska E, Wright HE Jr, Turner Ch (eds) Late Glacial and Holocene history of vegetation in Poland based on isopollen maps. W. Szafer Institute of Botany, Polish Academy of Sciences, Kraków, pp 337-346

Młynkowiak E, Kutyna I (2009) Zbiorowisko z Betula pendula i Populus tremula $\mathrm{w}$ zadrzewieniach środpolnych zachodniej części Pojezierza Drawskiego (Community with Betula pendula and Populus tremula in western part of Drawskie Lakeland). Folia Pomer Univ Technol Stetin Agric Aliment Pisc Zootech 271:113-126

Mooney SD, Tinner W (2011) The analysis of charcoal in peat and organic sediments. Mires Peat 7:1-18

Nalepka D, Walanus A (2003) Data processing in pollen analysis. Acta Palaeobot 43:125-134

O'Sullivan PE (1983) Annually laminated lake sediments and the study of Quaternary environmental changes. Quat Sci Rev $1: 245-313$

Obremska M, Ott F, Słowiński M, Lutyńska M, Błaszkiewicz M, Brauer A (2014) 2000 years of human activity in Tuchola Pinewoods (northern Poland). EGU General Assembly 2014, held 27 April-2 May, 2014 in Vienna, id 14827

Ohlendorf C, Sturm M (2008) A modified method for biogenic silica determination. J Paleolimnol 39:137-142

Ojala AEK, Alenius T, Seppä H, Giesecke T (2008) Integrated varve and pollen-based temperature reconstruction from Finland: evidence for Holocene seasonal temperature patterns at high latitudes. Holocene 18:529-538

Okulicz-Kozaryn Ł (1997) Dzieje Prusów. Leopoldinum, Wrocław

Okuniewska-Nowaczyk I, Makohonienko M, Latałowa M, Milecka K, Krupiński KM, Nalepka D (2004) Juniperus communis L.Juniper. In: Ralska-Jasiewiczowa M, Latałowa M, Wasylikowa K, Tobolski K, Madeyska E, Wright HE Jr, Turner Ch (eds) Late Glacial and Holocene history of vegetation in Poland based on isopollen maps. W. Szafer Institute of Botany, Polish Academy of Sciences, Kraków, pp 125-133

Oldfield F (1977) Lakes and their drainage basins as units of sediment-based ecological study. Prog Phys Geog 1:460504

Pawlikowski M, Ralska-Jasiewiczowa M, Schönborn W, Stupnicka E, Szeroczyńska K (1982) Woryty near Gietrzwałd, Olsztyn Lake District, NE Poland-vegetational history and lake development during the last 12000 years. Acta Paleobot 22:85-116

Pędziszewska A, Tylmann W, Witak M, Piotrowska N, Maciejewska E, Latałowa M (2015) Holocene environmental changes reflected by pollen, diatoms, and geochemistry of annual laminated sediments of Lake Suminko in the Kashubian Lake District (N Poland). Rev Palaeobot Palynol 216:55-75
Pidek IA, Svitavská-Svobodová H, van der Knaap WO et al (2010) Variation in annual pollen accumulation rates of Fagus along 840 a N-S transect in Europe based on pollen traps. Veget Hist Archaeobot 19:259-270

Pitkänen A, Huttunen P (1999) A 1300-year forest-fire history at a site in eastern Finland based on charcoal and pollen records in laminated lake sediment. Holocene 9:311-320

Pluskowski A (ed) (2013) The archaeology of the Prussian Crusades: Holy War and Colonisation. Routledge, London

Polakowski B (1961) Stosunki florystyczno-fitosocjologiczne Puszczy Boreckiej ze szczególnym uwzględnieniem lasów leśnictwa Lipowo i Walisko (Die floristisch-pflanzensoziologischen Verhältnisse der Puszcza Borecka mit besonderer Berücksichtigung der Försterei Lipowo und Walisko). Stud Soc Sci Tor 5:1-146

Polakowski B (1963) Stosunki geobotaniczne Pomorza Wschodniego (Die geobotanischen Verhältnisse im östlichen Pomorze). Zesz Nauk Wyższej Szkoły Rolniczej Olsztyn 15:3-167

Poska A, Saarse L, Veski S (2004) Reflections of pre- and earlyagrarian human impact in the pollen diagrams of Estonia. Palaeogeogr Palaeoclimatol Palaeoecol 209:37-50

Ralska-Jasiewiczowa M (1966) Osady denne jeziora Mikołajskiego na Pojezierzu Mazurskim w świetle badań paleobotanicznych [Bottom sediments of the Mikołajki Lake (Masurian Lake District) in the light of palaeobotanical investigations]. Acta Palaeobot 7:4-118

Ralska-Jasiewiczowa M, Goslar T, Madeyska T, Starkel L (eds) (1998) Lake Gosciąż, Central Poland, a monographic study. W. Szafer Institute of Botany, Polish Academy of Sciences, Kraków

Ralska-Jasiewiczowa M, Goslar T, Różański K, Wacnik A, Czernik J, Chróst L (2003) Very fast environmental changes at the Pleistocene/Holocene boundary, recorded in laminated sediments of Lake Gościąż, Poland. Palaeogeogr Palaeoclimatol Palaeoecol 193:225-247

Reimer PJ, Bard E, Bayliss A, Beck JW, Blackwell PG, Bronk Ramsey $C$ et al (2013) IntCal13 and Marine13 radiocarbon age calibration curves 0-50000 years cal BP. Radiocarbon $55: 1,869-1,887$

Seppä H, Alenius T, Muukkonen P, Giesecke T, Miller PA, Ojala AEK (2009) Calibrated pollen accumulation rates as a basis for quantitative tree biomass reconstructions. Holocene 19:209-220

Siuta J (1994) Stacja Kompleksowego Monitoringu Środowiska Puszcza Borecka. Instytut Ochrony Środowiska, Warszawa

Smykała J (1990) Historia, rozmiar i rozmieszczenie zalesień gruntów porolnych w Polsce w latach 1945-1987. Sylwan 3-12:61-74

Stančikaite M, Šinkūnas P, Risberg J, Šeirienè V, Blažauskas N, Jarockis R, Karlsson S, Miller U (2009) Human activity and the environment during the Late Iron Age and Middle Ages at the Impiltis archaeological site, NW Lithuania. Quat Int 203:74-90

Stanturf JA (ed) (2015) Restoration of Boreal and Temperate Forests, 2nd edn. Taylor \& Francis, Boca Raton

Stebich M, Brüchmann C, Kulbe T, Negendank JFW (2005) Vegetation history, human impact and climate change during the last 700 years recorded in annually laminated sediments of Lac Pavin, France. Rev Palaeobot Palynol 133:115-133

Stivrins N, Brown A, Veski S, Ratniece V, Heinsalu A, Austin J, Liiv M, Cerina A (2015a) Palaeoenvironmental evidence for the impact of the crusades on the local and regional environment of medieval (13th-16th century) northern Latvia, eastern Baltic. Holocene. doi:10.1177/0959683615596821

Stivrins N, Brown A, Reitalu T, Veski S, Heinsalu A, Banerjea RY, Elmi K (2015b) Landscape change in central Latvia since the Iron Age: multiproxy analysis of the vegetation impact of conflict, colonization and economic expansion during the last 2000 years. Veget Hist Archaeobot 24:377-391 
Stockmarr J (1971) Tablets with spores used in absolute pollen analysis. Pollen Spores 13:615-621

Sturm M (1979) Origin and composition of clastic varves. In: Schlüchter C (ed) Moraines and Varves. Balkema, Rotterdam, pp 281-285

Sugita S (2007a) Theory of quantitative reconstruction of vegetation I: pollen from large sites REVEALS regional vegetation composition. Holocene 17:229-241

Sugita S (2007b) Theory of quantitative reconstruction of vegetation II: all you need is LOVE. Holocene 17:243-257

Szafer W, Zarzycki K (eds) (1972) Szata roślinna Polski, Tom II. PWN, Warszawa

Szal M, Kupryjanowicz M, Wyczołkowski M, Tylmann W (2014) The Iron Age in the Mragowo Lake District, Masuria, NE Poland: the Salęt settlement microregion as an example of longlasting human impact on vegetation. Veget Hist Archaeobot 23:319-338

Szeliga J (1997) Rękopiśmienne mapy Prus Książęcych Józefa Naronowicza-Narońskiego z drugiej połowy XVII wieku. Studia i Materiały z Historii Kartografii 15. Biblioteka Narodowa, Warszawa

Theuerkauf M, Dräger N, Kienel U, Kuparinen A, Brauer A (2015) Effects of changes in land management practices on pollen productivity of open vegetation during the last century derived from varved lake sediments. Holocene 25:733-744

Tinner W, Lotter AF (2006) Holocene expansions of Fagus silvatica and Abies alba in Central Europe: where are we after eight decades of debate? Quat Sci Rev 25:526-549

Tinner W, Lotter AF, Ammann B, Conedera M, Hubschmid P, van Leeuwen JFN, Wehrli M (2003) Climatic change and contemporaneous land-use phases north and south of the Alps $2300 \mathrm{BC}$ to $800 \mathrm{AD}$. Quat Sci Rev 22:1,447-1,460

Toeppen M (1870) Historia Mazur. Przyczynek do dziejów Krainy i kultury pruskiej (Geschichte Masurens. Ein Beitrag zur preußischen Landes- und Kulturgeschichte) (trans: Szymańska-Jasińska M, 1995) Jasiński G (eds). Borussia, Olsztyn

Trondman A, Gaillard M, Mazier F, Sugita S, Fyfe R et al (2015) Pollen-based quantitative reconstructions of Holocene regional vegetation cover (plant-functional types and land-cover types) in Europe suitable for climate modelling. Glob Chang Biol 21:676-697

Tylmann W, Zolitschka B, Enters D, Ohlendorf C (2013) Laminated lake sediments in northeast Poland: distribution preconditions for formation and potential for paleoenvironmental investigation. J Paleolimnol 50:487-503
Tylmann W, Bonk A, Goslar T, Wulf S, Grosjean M (2016) Calibrating ${ }^{210} \mathrm{~Pb}$ dating results with varve chronology and independent chronostratigraphic markers: problems and implications. Quat Geochronol 32:1-10

Veski S, Koppel K, Poska A (2005) Integrated palaeoecological and historical data in the service of fine-resolution land use and ecological change assessment during the last 1000 years in Rõuge, southern Estonia. J Biogeogr 32:1,473-1,488

Vogel H, Rosén P, Wagner B, Melles M, Persson P (2008) Fourier transform infrared spectroscopy, a new cost-effective tool for quantitative analysis of biogeochemical properties in long sediment records. J Paleolimnol 40:689-702

Voigt R, Grüger E, Baier J, Meischner D (2008) Seasonal variability of Holocene climate: a palaeolimnological study on varved sediments in Lake Jues (Harz Mountains, Germany). J Paleolimnol 40:1,021-1,052

Wacnik A, Goslar T, Czernik J (2012) Vegetation changes caused by agricultural societies in the Great Mazurian Lake District. Acta Palaeobot 52:59-104

Wacnik A, Kupryjanowicz M, Mueller-Bieniek A, Karczewski M, Cywa K (2014) The environmental and cultural contexts of the late Iron Age and medieval settlement in the Mazurian Lake District, NE Poland: combined palaeobotanical and archaeological data. Veget Hist Archaeobot 23:439-459

Ważny $\mathrm{T}$ (2005) The origin, assortments and transport of Baltic timber. In: Van de Velde C, Beeckman H, Van Acker J, Verhaeghe F (eds) Constructing Wooden Images. Proceedings of the Symposium on the organization of Labour and working practices of Late Gothic carved altarpieces in the Low Countries, Brussels 25-26 October 2002. VUB, Brussels, pp 115-126

Wersin P, Höhener P, Giovanoli R, Strumm W (1991) Early diagenetic influences on iron transformations in a freshwater lake sediment. Chem Geol 90:233-252

Więcko E (1979) Gospodarstwo leśne i przemysł drzewny w Polsce. Państwowe Wydawnictwo Rolne i Leśne, Warszawa

Woś A (1999) Klimat Polski. Wydawnictwo Naukowe PWN, Warszawa

Zając A, Zając M (2001) Atlas rozmieszczenia roślin naczyniowych w Polsce. Edited by Laboratory of Computer Chorology, Jagiellonian University, Institute of Botany, Kraków

Zasada M, Sz Bijak, Bronisz K, Bronisz A, Gawęda T (2014) Biomass dynamics in young silver birch stands on postagricultural lands in central Poland. Drewno 57(192):29-39

Zolitschka B, Francus P, Ojala AEK, Schimmelmann A (2015) Varves in lake sediments: a review. Quat Sci Rev 117:1-41 